\title{
A taxonomic revision of Solenostomataceae (Marchantiophyta) in Korea
}

\author{
Vadim V. BAKALIN, Seung Se CHOI ${ }^{*}$, Seung Jin PARK ${ }^{2}$, \\ Sun Hee SIM ${ }^{3}$ and Chang Woo HYUN ${ }^{3}$ \\ Botanical Garden-Institute, Vladivostok 690024, Russia \\ ${ }^{1}$ Department of Natural Environment Research, National Institute of Ecology, Seocheon 33657, Korea \\ ${ }^{2}$ Department of Biological Sciences, Jeonbuk National University, Jeonju 54896, Korea \\ ${ }^{3}$ Plant Resources Division, National Institute of Biological Resources, Incheon 22755, Korea \\ (Received 14 February 2020; Revised 8 June 2020; Accepted 23 June 2020)
}

\begin{abstract}
Solenostomataceae are revised for the Korean Peninsula. In total, 27 species in four genera (Metasolenostoma, Plectocolea, Protosolenostoma, Solenostoma) are recorded, the occurrence of 24 of which is confirmed. Each confirmed species is provided with an ecological overview, and a list of specimens examined and illustrations based on materials from Korea. Solenostoma jirisanense sp. nov. is described.
\end{abstract}

Keywords: Solenostomataceae, Plectocolea, Solenostoma, Metasolenostoma, Protosolenostoma, taxonomy

The Solenostomataceae were described by Crandall-Stotler et al. (2009) to include the series of genera previously regarded as members of the Jungermanniaceae. Since then the circumscription of family was modified several times by transfers of genera to other families (e.g., Endogemmataceae, cf. Vilnet et al., 2011), synonymization of known genera (e.g., Scaphophyllum and some species of Gottschelia with Solenostoma, cf. Feldberg et al., 2009) and the descriptions of new genera (e.g., Protosolenostoma and Metasolenostoma, cf. Bakalin et al., 2014). The last valuable emendation was the transfer of Nardia to Gymnomitriaceae (Shaw et al., 2015). Therefore, considering the aforementioned novelties, the Solenostomataceae is represented in Korea by four genera: Metasolenostoma, Plectocolea, Protosolenostoma and Solenostoma, all of which are more or less closely related morphologically.

Outside of Japan and the southern part of the Russian Far East the taxonomy and distribution patterns of the Solenostomataceae are poorly understood in East Asia. Several species were recorded for various provinces in China and the Korean Peninsula. Unfortunately, these data are too fragmentary and incline one to suspect disjunctive distributions for many taxa, especially in China. Additionally, some records may be based on misidentifications and the specimens on which the record is based are unavailable for revisions. The latter is fully applicable not only to China, which is not the object of the present study, but also to the Korean Peninsula. On the one hand specimens from North Korea, collected within last 60 years, are absolutely unavailable to foreigners (including South Koreans); on another hand many records from South Korea published by Yamada and Choe (1997) as well as Hong (1962) also could not be checked. We studied the collections in the three largest herbaria in Japan: TNS, HIRO, and NICH, with particular attention to the latter two, where the specimens studied by these Korean authors should have been deposited but found only a few materials for widely distributed taxa that was of little help to us in the preparation in this account. In fact, we were forced to study the Solenostomataceae in Korea from scratch, and this process was started in 2008.

\section{Materials and Methods}

This paper is based on materials collected by us (mostly by Choi and Bakalin) within the last twelve years in numerous localities across the Republic of Korea and deposited in JNU, $\mathrm{KB}$, and VBGI. These collections far exceed the previously known materials collected in South Korea and may be regarded as rather exhaustive for South Korea. Although we did not

\footnotetext{
*Author for correspondence: hepaticae@nie.re.kr
} 


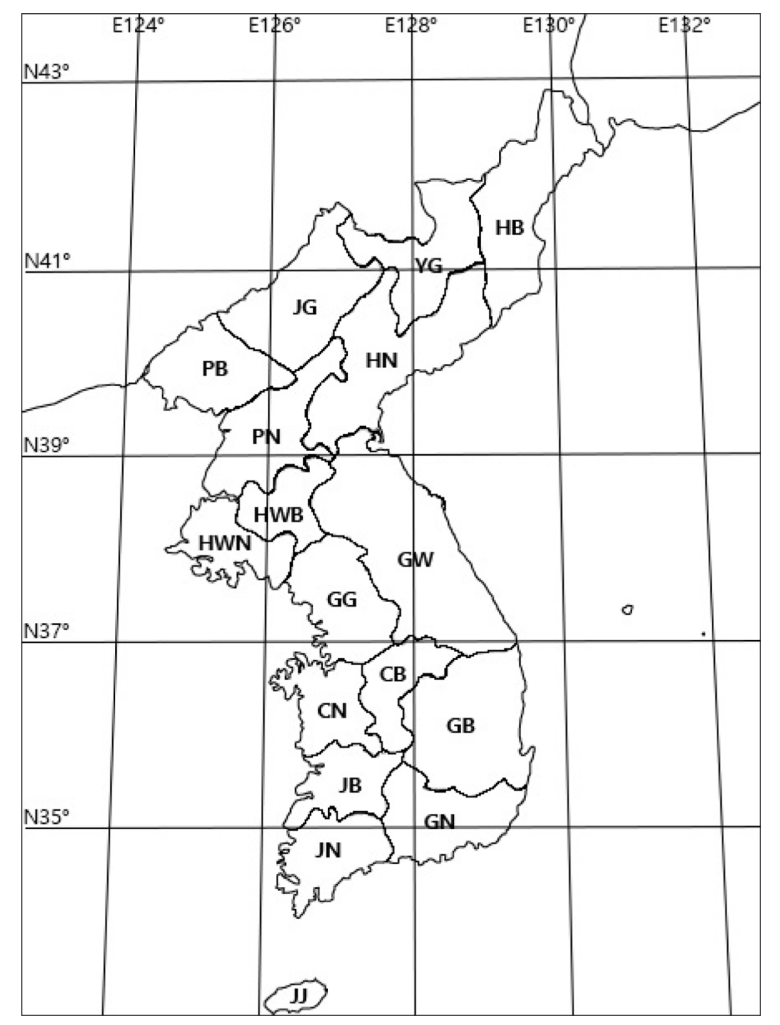

Fig. 1. Provinces of the Korean Peninsula into administrative subunits. $\mathrm{CB}$, Chungcheongbuk-do; CN, Chungcheongnam-do; GB, Gyeongsangbuk-do; GN, Gyeongsangnam-do; GG, Gyeonggi-do; GW, Gangwon-do; HB, Hamgyeongbuk-do; HN, Hamgyeongnam do; HWB, Hwanghaebuk-do; HWN, Hwanghaenam-do; JB, Jeollabuk-do; JG, Jagang-do; JN, Jeollanam-do; JJ, Jeju-do; PB, Pyeonganbuk-do; PN, Pyeongannam-do; YG, Yanggang-do.

have access to North Korean specimens, we prefer to include in this revision the data on the distribution of taxa in North Korea, based on literature sources, mainly those summarized by Kim and Hwang (1991) and Yamada and Choe (1997). The distribution of taxa within Korea is given in accordance with the official subdivision of the country (Fig. 1).

Each species treatment is accompanied by data on ecology (sometimes with list of accompanying liverwort taxa, where nomenclature mostly follows to Konstantinova et al., 2009), distribution patterns (with main attention to the Korean Peninsula), list of specimens examined and comments (mostly to help in the separation of morphologically closely related taxa). The data on distribution in adjacent areas are from Bakalin (2014a) for the Russian Far East, Piippo (1990) for China and Amakawa (1960), Yamada and Iwatsuki (2006) for Japan, with some additional information from recent literature (cited where used). The taxa for which we were unable to confirm or to study specimens from Korea proper are only discussed and provided with references for papers where figures may be obtained. The nomenclature citation for each species includes only a few synonyms, mostly those names that were previously used for the Korean Peninsula. Here we do not describe the identification and descriptions of each species, genus, and Solenostomataceae, the overview of taxonomically valuable features or the history of generic understanding, because it was published very recently (Bakalin, 2014a; Bakalin and Choi, 2017) and need not be repeated. The synonyms after species name are provided only if they were used to indicate the species for the Korean Peninsula in the literature.

\section{Taxonomic Treatments}

Solenostomataceae Stotler \& Crand.-Stotl., Edinburgh J. Bot. 66: 190, 2009. 둥근망울이끼과

There are four genera and 24 taxa recorded in the Korean Peninsula.

I. Metasolenostoma Bakalin \& Vilnet, Bot. Pacif. 3: 10, 2014. Korean name: O-reum-mang-ul-i-kki-sok (오름망울이끼속).

An oligotypic recently described genus with one species known in Korean Peninsula (Bakalin et al., 2014).

1. Metasolenostoma ochotense Vilnet et Bakalin, Bot. Pacif. 3: 10, 2014 (Fig. 2). Solenostoma ochotensis Bakalin \& Vilnet, The Bryologist 115: 575, 2012.

Korean name: O-reum-mang-ul-i-kki (오름망울이끼).

Ecology: Acidophilic hygrophyte. In the Kurils, where the species is the most common, it is commonly inclined to occupy volcanically modified habitats (the taxon described from wet scoria field). In adjacent areas this taxon preferentially grows in the places with disturbed vegetation cover in open to shaded areas within broad-leaved deciduous to boreal dark coniferous forest zones.

Distribution: This is a boreal East Asian species with a distribution covering Kamchatka, Kurils, Sakhalin, northern Japan and the Korean peninsula, thus the lands under the influence of Pacific wet air masses. The occurrences in the Korean Peninsula are in the southwestern flank of the species area and represent poorly developed modifications (similar to that in the Kamchatka Peninsula).

Comments: The known populations in Korea represent leptodermous modification of the species (also common in Kamchatka Peninsula in North-East Asia) characterized by pellucid, very pale-colored plants and small concave trigones 

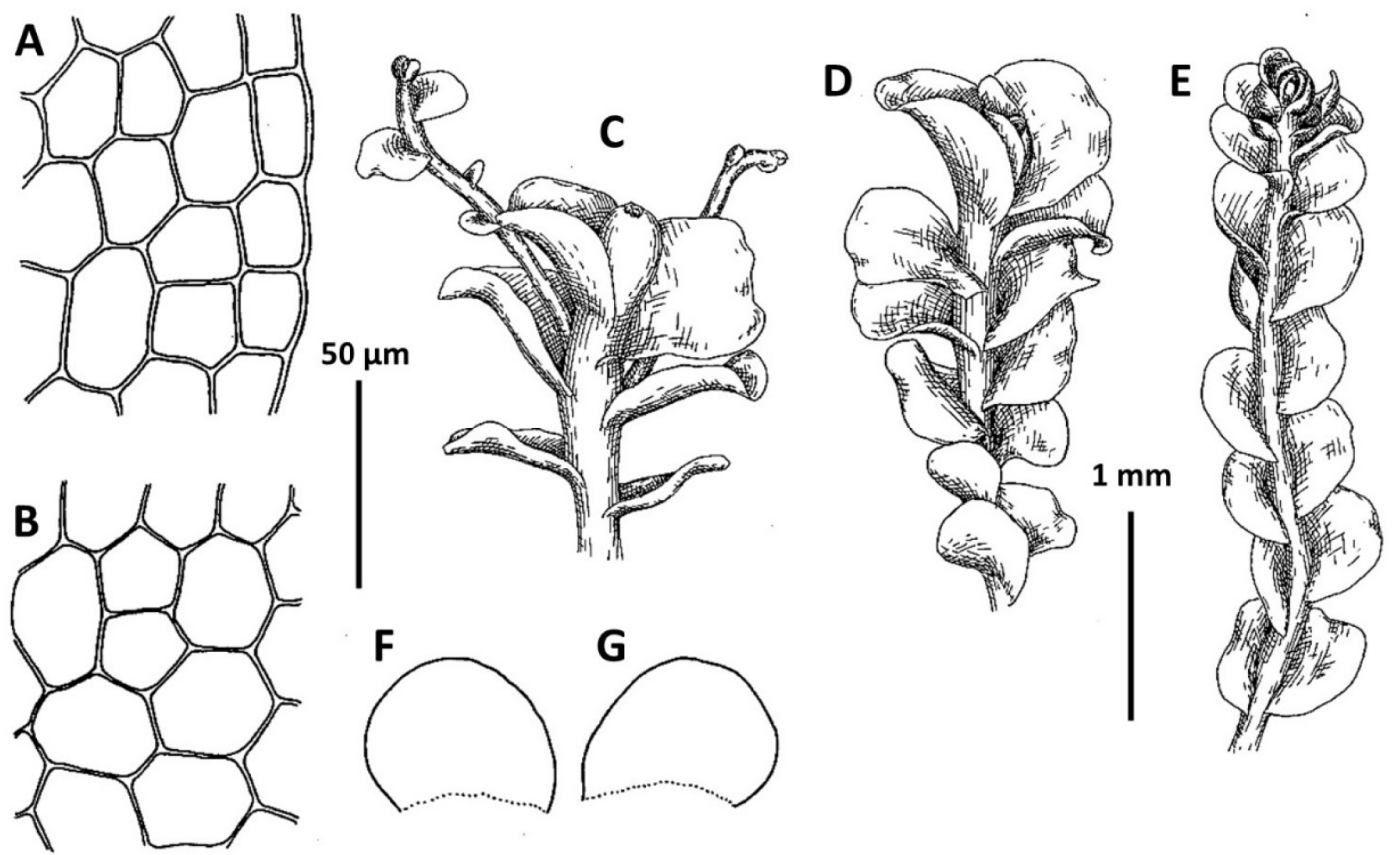

Fig. 2. Metasolenostoma ochotense Vilnet et Bakalin. A. Cells along leaf margin. B. Cells in the leaf middle. C, D. Perianthous branch with young unfertilized perianth. E. Male branch. F, G. Leaves (from Choi 633). Scale bars $=50 \mu \mathrm{m}(\mathrm{A}, \mathrm{B}), 1 \mathrm{~mm}(\mathrm{C}-\mathrm{G})$.

in leaf cells. Perianth are not known from the Korean Peninsula. Among regional taxa, leptodermous modifications of this species may be probably mistaken with Protosolenostoma fusiforme, from which it differs by its small, but distinct trigones of leaf cells, as well as the smaller size of leaf cells (in P. fusiforme mostly larger than $40 \times 30 \mu \mathrm{m}$ in the midleaf), absence of an evident leaf rim and also its occurrence at lower altitudes in the peninsula ( $P$. fusiforme known from high to middle elevations in Jeju-do Island only). The records of Plectocolea hyalina for Chungcheongbuk-do, Gyeonggi-do, and Gangwon-do (Yamada and Choe, 1997) may be based on misidentification of Metasolenostoma ochotense. Our previous record of Plectocolea hyalina for Namchae Island (Bakalin, 2014a) also belongs to the latter taxon. Metasolenostoma ochotense differs from Plectocolea hyalina in a pellucid (versus dull) appearance, short perigynium (less that $1 / 2$ of perianth length versus longer than 1/2), generally typical 'solenostomoid' keeled and beaked perianth composed by subisodiametric to shortly oblong cells (versus cells twice as long as wide in P. hyalina).

II. Plectocolea (Mitt.) Mitt., Flora Vitiensis 405, 1873. Solenostoma subgen. Plectocolea Mitt., J. Proc. Linn. Soc. 8: 156, 1865; Jungermannia L. subg. Plectocolea (Mitt.) Amakawa J. Hattori Bot. Lab., 21: 270, 1960.

Korean name: Keun-ip-mang-ul-i-kki-sok (큰잎망울이끼속).
A large genus counting over 60 taxa in East to South-East Asia, with its center of diversity in warm temperate mountains near the Pacific Ocean. 15 species are recorded in the Korean Peninsula.

1. Plectocolea comata (Nees) S. Hatt. Bull. Tokyo Sci. Mus. 11: 38, 1944 (Figs. 3, 20B-D). Jungermannia comata Nees, Enum. Pl. Crypt. Jav. 78, 1830.

Korean name: Bi-jja-ru-mang-ul-i-kki (비짜루망울이끼).

Ecology: Acido- to neutrophilic meso-hygrophyte, occupying bare fine mineral soil along streams (but outside of direct impact by water) in partly shaded areas, forming pure mats.

Distribution: Tropical-subtropical East Asian species, widely distributed in lowlands covered by evergreen vegetation. From adjacent lands it is recorded in southern Japan, Chinese Liaoning (this report seems to be doubtful), Yunnan and Taiwan. Plectocolea comata reflects southern relations in the Korean flora and is restricted in distribution to the southernmost flank of the area treated. It was recorded for Gyeongsangbuk-do, Chungcheongbuk-do, Gyeongsangbuk-do, Gyeongsangnam-do (Yamada and Choe, 1997), but at least some of reports may be based on misidentifications.

Comments: This is a fairly distinct species that is difficult to mistake with other Solenostomataceae. Its distinct features 


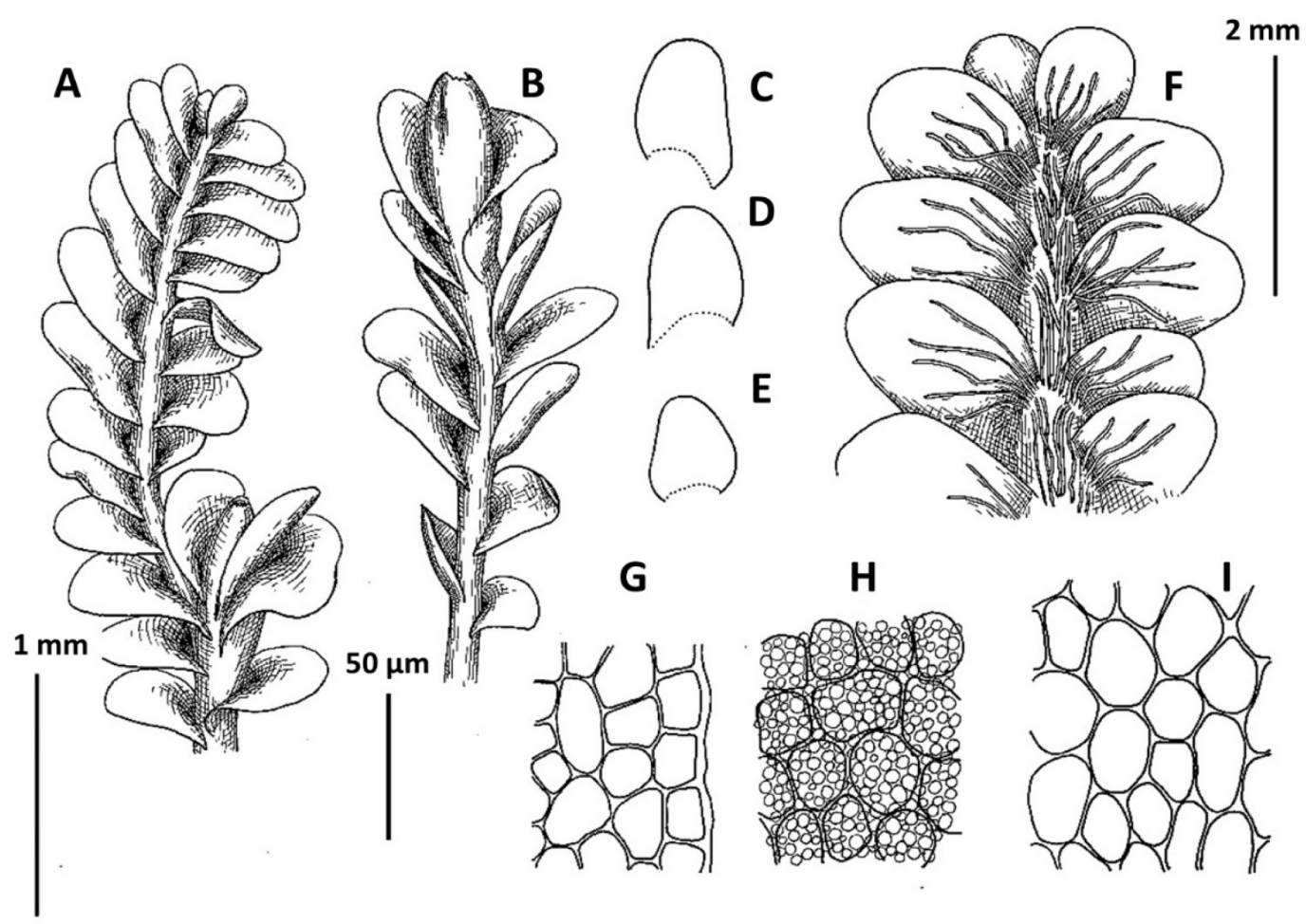

Fig. 3. Plectocolea comata S. Hatt. A, B. Perianthous branch, view from dorsal side. C-E. Leaves. F. Branch fragment, view from ventral side. G. Cells along leaf margin. H. Midleaf cells, showing papillae. I. Midleaf cells (all from Choi 120873). Scale bars $=1 \mathrm{~mm}(\mathrm{~A}-\mathrm{E}), 2 \mathrm{~mm}$ (F), $50 \mu \mathrm{m}(\mathrm{G}-\mathrm{I})$.

include pale color, prostrate growth form, colorless to brownish rhizoids with some of them spreading upward over the outer leaf surface and (in particular) a coarsely verrucose leaf cuticle. However, it has been mistaken in the herbarium with Plectocolea truncata (also southern in distribution and even more broadly distributed in the tropics in comparison with $P$. comata). The two species differ in (1) leaf shape (wider than long, with commonly truncate apex in P. truncata versus longer than wide with rounded apex), (2) cells along leaf margin (equally to subequally thickened versus rather thin-walled to strongly subequally thickened due to a confluence of trigones), (3) leaf cuticle (nearly smooth to papillose versus coarsely verrucose), (4) rhizoid color and orientation (colorless and brownish to pinkish and purplish, variously spreading, but never going upward over outer leaf surface versus colorless to brownish rarely with pink tint and commonly going upward over outer leaf surface). Another rather rare and still poorly understood taxon with which confusion seems to be possible is $P$. granulata. The latter differs from $P$. comata in sparse and invariable purple and rigid rhizoids never going upward over outer leaf surface (versus merely dense, colorless to brownish, soft and with some going upward over outer leaf surface), clearly papillose leaf cuticle (versus coarsely verrucose) and leptodermous midleaf cells with small and concave trigones (versus trigones moderate in size to large and convex).

2. Plectocolea erecta Amakawa, J. Jap. Bot. 42: 307. f. 9: c; 10, 1957 (Figs. 4, 6A, 20E-I). Jungermannia erecta (Amakawa) Amakawa, J. Hattori Bot. Lab. 22: 13, 1960.

Korean name: Got-eun-mang-ul-i-kki (곧은망울이끼).

Ecology: The species occupies partly shaded (rarely open) moist cliffs and stones, mostly beside direct impact of running water in the deciduous forest zone, forming deep green to brown, purple and blackish, pure patches or, rarely, in admixture with Marsupella spp.

Distribution: Temperate East Asian species, known in adjacent areas from Chinese Jilin and Liaoning, as well as from Japan (being more or less common in southern half of the latter). Recorded for Jeollanam-do, Gangwon-do, Pyongyang (Yamada and Choe, 1997), also confirmed for Chungcheongnam-do, Gyeongsangbuk-do, Gyeongsangnamdo, Jeju-do, Jeollabuk-do.

Comments: In the context of a regional flora this very peculiar species may be mistaken with Solenostoma obscurum. Both taxa share a rigid structure, deep purple rhizoids, semi- 


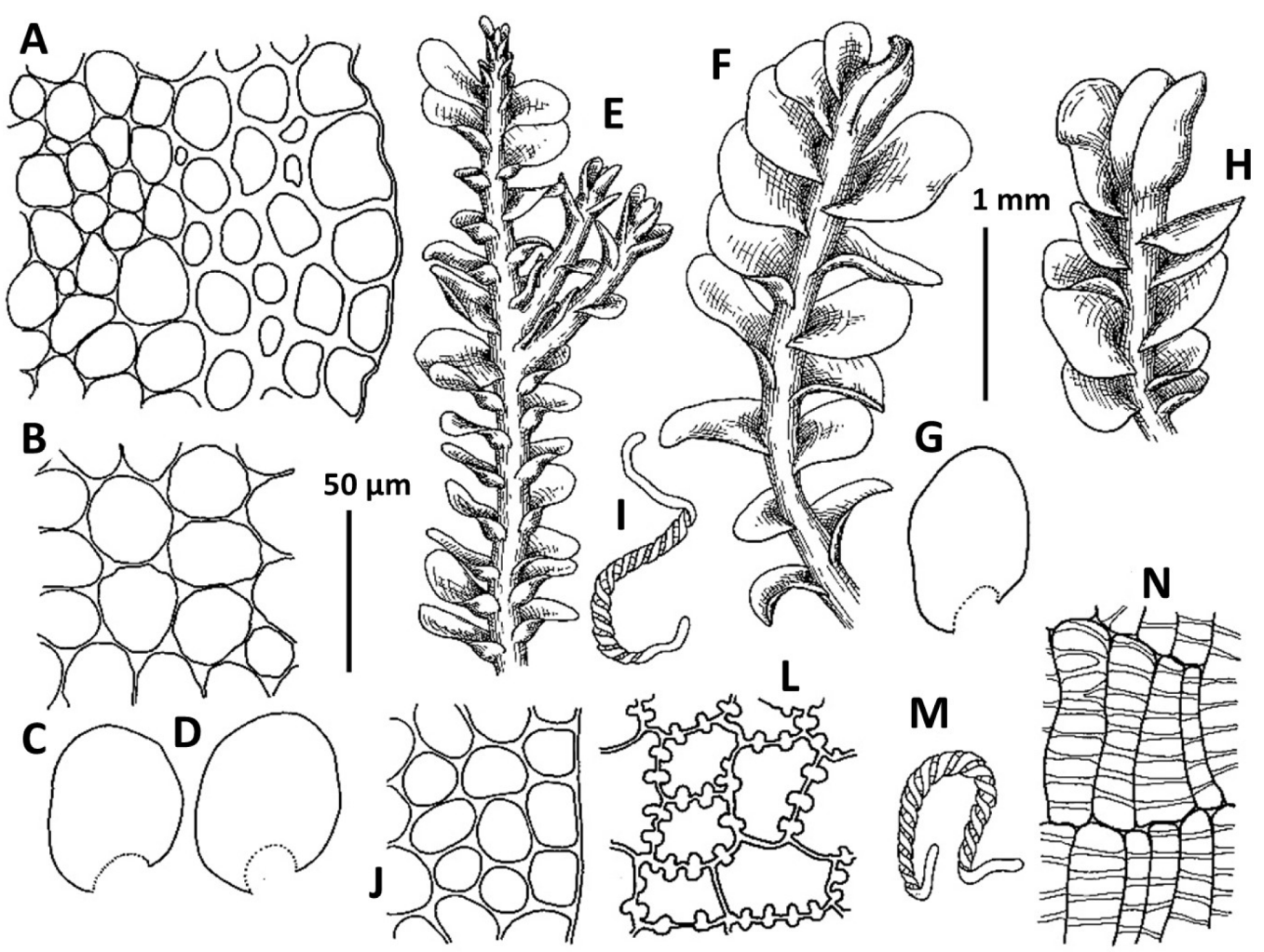

Fig. 4. Plectocolea erecta Amakawa. A. Stem cross section segment. B. Midleaf cells. C, D, G. Leaves. E. Male branch. F, H. Female branches. I, L. Elaters. J. Cells from leaf margin. K. Capsule wall outer layer. M. Capsule wall inner layer (from Choi 110403). Scale bars $=50 \mu \mathrm{m}(\mathrm{A}, \mathrm{B}, \mathrm{I}-\mathrm{M}), 1 \mathrm{~mm}(\mathrm{C}-\mathrm{H})$.

erect growth and (in a manner) habitat preferences. However the two taxa strikingly differ in (1) rhizoids, those form distinct fascicles decurrent down the stem in Plectocolea erecta, versus non-fasciculate rhizoids in Solenostoma obscurum, (2) perigynium shorter than $1 / 2$ of perianth length, versus perigynium longer than 1.5 of perianth length, (3) general distribution whereas Plectocolea erecta occupies the southern flank of the Korean Peninsula (that is near the northern extreme of worldwide species distribution) versus worldwide southernmost locality of Solenostoma obscurum is in northern part of South Korea (Seorak Mt.), at rather high altitudes.

Confusion seems to be also possible with Plectocolea virgata, which shares an erect growth form and fasciculate rhizoids with $P$. erecta. However, the two species distinctly differ in marginal cell characteristics with $P$. virgata having mostly equally to subequally thickened walls with small to indistinct trigones and finely papillose cuticle, versus thin to unequally thickened walls with large trigones and smooth cuticle in P. erecta. Other differences are in (1) rhizoid color that in the erect part of stem is purple in $P$. erecta, but commonly colorless to purplish in $P$. virgata, (2) obliquely oriented leaves in $P$. erecta versus subtransversely ones in P. virgata and (3) 1-2(3) special, finely papillose oil bodies in $P$. virgata versus 3-6 mostly ellipsoidal and granulate oil bodies in $P$. erecta.

3. Plectocolea granulata (Steph.) Bakalin, Polish Bot. J. 58: 132, 2013 (Fig. 5A-F). Nardia granulata Steph., Bull. Herb. Boissier 5: 100, 1897.

Korean name: Yeol-dae-mang-ul-i-kki (열대망울이끼).

Ecology: The species occupies partly shaded habitats where it grows on bare, fine soils along trailside and watercourses.

Distribution: Tropical-subtropical East Asian species, in adjacent areas known from the southern half of Japan, occurring southward in Indo-China. Generally subtropical in distribution, this species is restricted to the southern flank of the area treated (Jeju-do). The distribution of this species remains poorly understood due to the very questionable 'solution' by Váňa (Váňa and Inoue, 1983) who combined $P$. granulata and as well as other distinct species (like $P$. shinii, P. polyrhizoides, etc.) into a 'Plectocolea truncata' portmanteau (cf. Bakalin et al., 2014). 


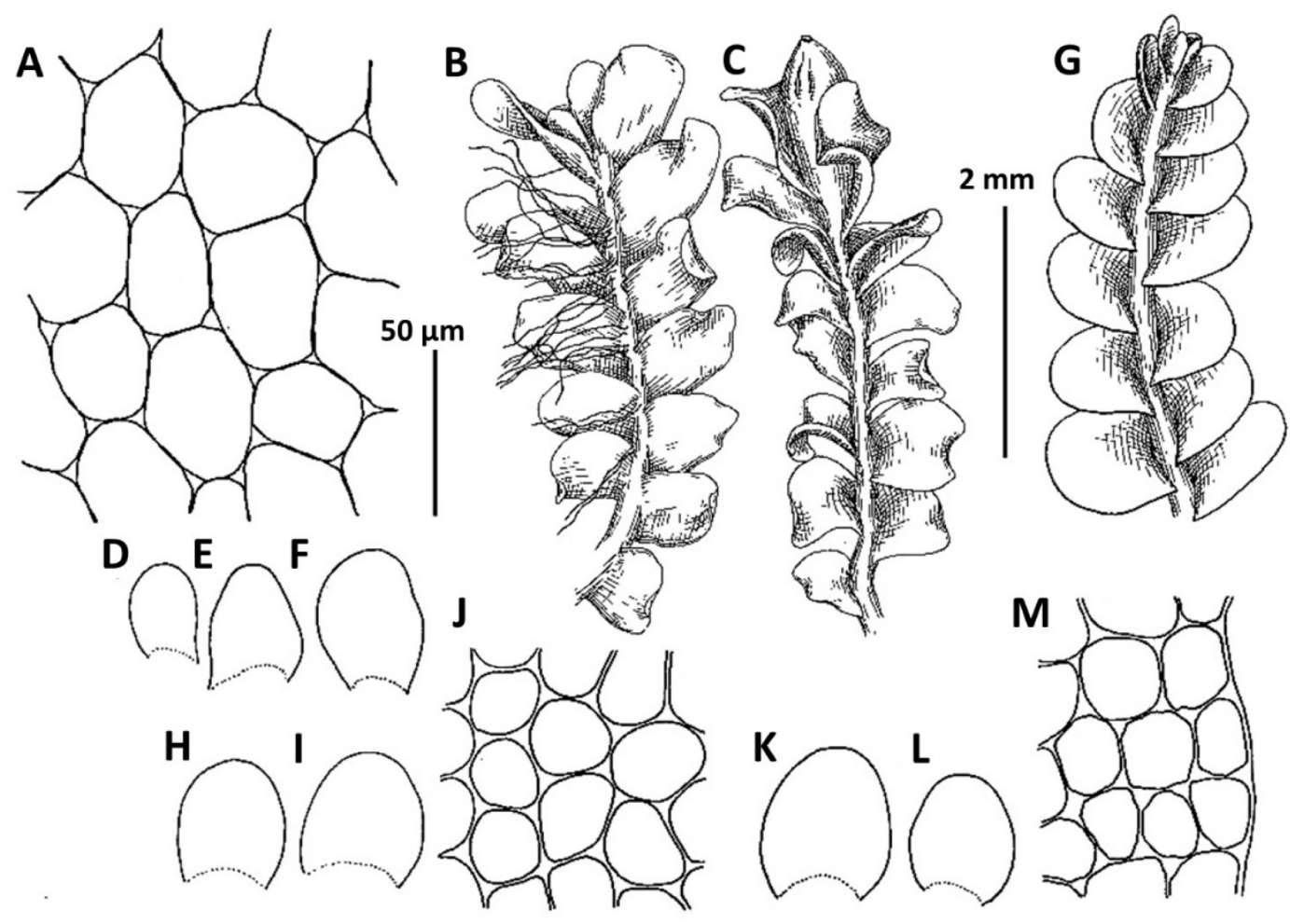

Fig. 5. Plectocolea granulata (Steph.) Bakalin. A-F. A. Midleaf cells. B. Sterile branch, view from ventral side. C. Perianthous branch, view from dorsal side. D-F. Leaves. (from Choi 8019). Plectocolea infusca var. recondita Bakalin. G-M. G. Sterile branch. H, I, K, L. Leaves. J. Midleaf cells. M. Cells along leaf margin (from Choi 2-14). Scale bars $=50 \mu \mathrm{m}(\mathrm{A}, \mathrm{J}, \mathrm{M}), 2 \mathrm{~mm}(\mathrm{~B}-\mathrm{I}, \mathrm{K})$.

Comments: This is a rather distinct species with confusion possible only with $P$. comata. The differences between the two taxa are discussed under the latter.

4. Plectocolea grossitexta (Steph.) S. Hatt., Bull. Tokyo Sci. Mus. 11: 38, 1944 (Fig. 6B-I). Jungermannia grossitexta Steph., Sp. Hepat. 6: 87, 1917.

Korean name: Ba-da-mang-ul-i-kki (바다망울이끼).

Ecology: Acidophilic mesophyte, growing in the Korean Peninsula in moist soil in partial shade under the canopy of broadleaf-evergreen forests in the southern half of Jeju-do.

Distribution: A warm temperate-subtropical East Asian species, sparsely occurring in southern Japan and known from one locality in Korea proper (Jeju-do). The distribution of the species is poorly understood due to the fact it was regarded as synonymous with Plectocolea torticalyx. However, we prefer to keep it separate as was treated by Bakalin (2014b).

Comments: Perianthous plants are not known in Korea and their description may be found in Bakalin (2014b). The species seems to be closely related to Plectocolea torticalyx, from which it is different in a low perigynium (less $1 / 2$ of perianth length, versus perigynium longer than the perianth), colorless to brownish and brown rhizoids (versus almost invariably purple) and leaves longer than wide (versus distinctly wider than long). Some differences may also be observed in plant texture (softer and laxer in P. grossitexta).

5. Plectocolea infusca Mitt., Trans. Linn. Soc. London, Bot. 3: 196, 1891. Jungermannia infusca (Mitt.) Steph., Bull. Herb. Boissier, sér. 2, 1: 512, 1901; Solenostoma infuscum (Mitt.) Hentschel, Plant Syst. Evol. 268: 152, 2007.

There two varieties of the species are occurring in the peninsula and they are discussed separately.

\section{5a. Plectocolea infusca Mitt. var. infusca}

Korean name: Keun-mang-ul-i-kki (큰망울이끼).

Ecology: Acidophilic meso-hygrophyte, occupying partly shaded or (rarely) open habitats, where it grows on stones and cliffs along streams, but not in constant (or even continuous) impact of running water. Also, the variety is widely spread in 


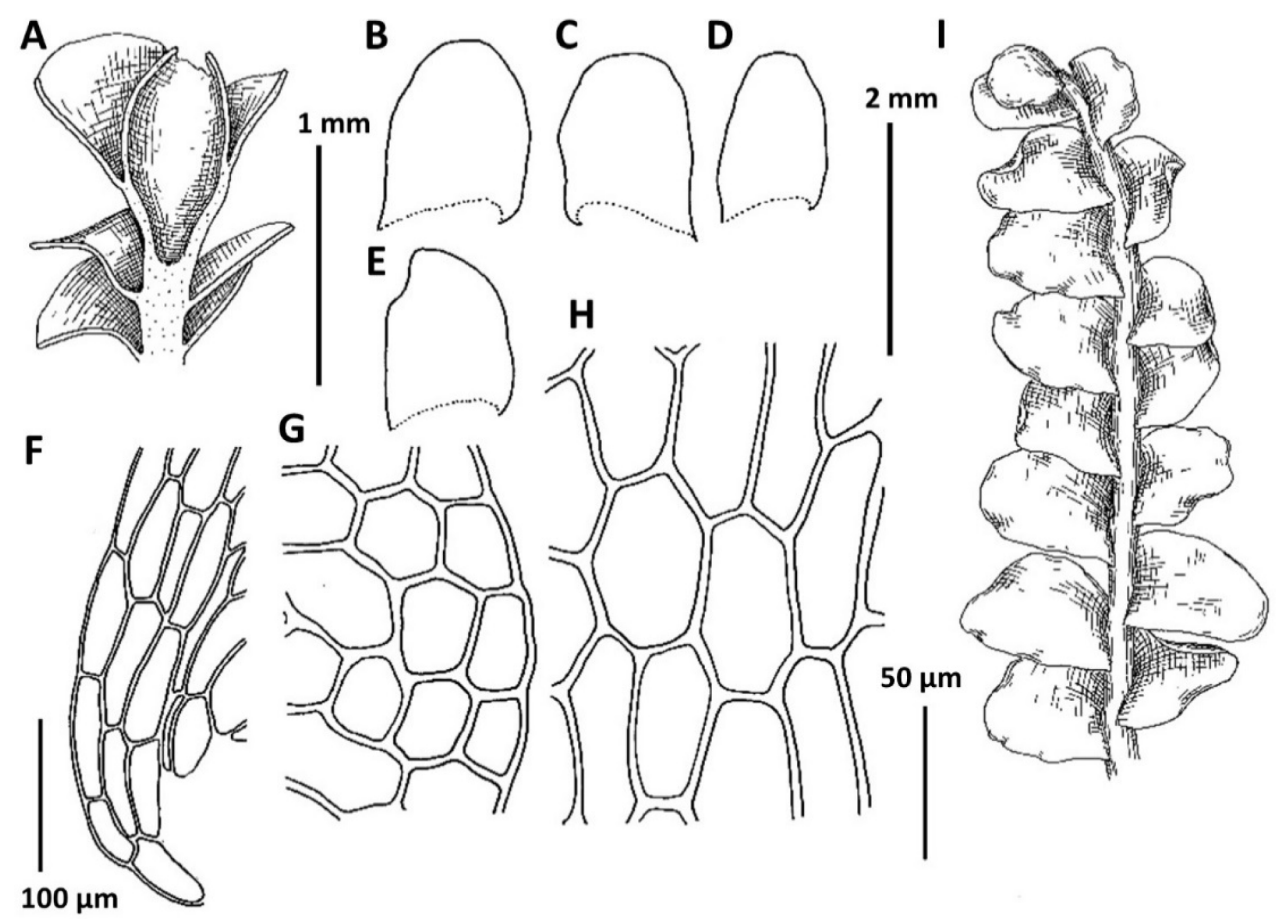

Fig. 6. Plectocolea erecta Amakawa. A. Perianth longitudinal section (from Choi 110403). Plectocolea grossitexta (Stephani) S. Hatt. B-I. BE. Leaves. F. Cells near ventral leaf base. G. Cells along leaf margin. H. Midleaf cells. I. Sterile branch (from Choi 8057). Scale bars $=1 \mathrm{~mm}$ (A), $2 \mathrm{~mm}(\mathrm{~B}-\mathrm{E}, \mathrm{I}) ; 100 \mu \mathrm{m}(\mathrm{F}), 50 \mu \mathrm{m}(\mathrm{G}, \mathrm{H})$.

human-disturbed areas, such as roadsides and trails. In general, this is a taxon of broadleaved temperate lowlands but widely penetrates the subtropics (East China and southern Japan), as well as to hemiboreal forests northward.

Distribution: Temperate-North Subtropical East Asian variety, where it is the most common representative of the family. The area of the variety covers the southern half of the Russian Far East, Japan and East China. The taxon also 'should' occur in Indochina, but there is no data confirming this. In the Korean Peninsula it has been recorded from Jejudo, Jeollanam-do, Jeollabuk-do, Chungcheongnam-do, Gyeongsangnam-do, Gangwon-do, Pyongyang (Kim and Hwang, 1991; Yamada and Choe, 1997); we suggest it should be present in all provinces of the region.

Comments: The easiest way to recognize this taxon is to study oil-bodies while plants are still alive (sometimes oilbodies are preserved for several years in the herbarium, but far from always). The distinctive brownish, large oil-bodies filling cell lumina ('infusca'-type of Amakawa 1960) preclude misidentification and only distinctions from Plectocolea infusca var. recondita need to be taken into account (given under the latter). However, when a specimen is dried, misidentification in readily possible with $P$. kurilensis and $P$. ovalifolia (both characterized by smaller and grayish oil-bodies not filling cell lumina). Plectocolea ovalifolia differs from $P$. infusca in ovate, longer than wide leaves and almost constantly purple rhizoids (versus leaves wider than long and rhizoids mostly colorless, with rare admixture of purplish or even purple). Dried $P$. kurilensis differs from $P$. infusca in commonly undulate and sometimes widely recurved antical leaf margins in the uppermost leaves, the frequent presence of purplish pigmentation in rhizoids and the common presence of ventral geotropic leafless stolons (versus leaves more stout and not undulate even in the apical part of the shoot, purplish pigmentation of rhizoids occurs as a rarity and geotropic leafless stolons are absent). Additionally, P. infusca commonly spreads into man-made habitats, but this was not observed in P. kurilensis. Additional discussion on variability perimeters of the both species may be found in Bakalin (2014a).

5b. Plectocolea infusca var. recondita Bakalin, Bot. Pacif. 3: 86, 2014 (Fig. 5G-M, 20J). Jungermannia infusca var. ovicalyx (Steph.) Amakawa, J. Hattori Bot. Lab. 22: 33, 1960, auct. non.; Plectocolea infusca var. ovicalyx (Steph.) Bakalin, Arctoa 17: 207, 2007; Solenostoma ovicalyx Steph., Sp. Hepat. 6: $82,1917$. 
Korean name: San-keun-mang-ul-i-kki (산큰망울이끼).

Ecology: Acidophilic mesophyte. The intergrading zone or belt between hemiboreal coniferous and broadleaved deciduous forests is the most favorable area of the variety. Contrary to var. infusca, var. recondita prefers more mesic places, occupying partially shaded bare fine mineral soils on steep slopes or crumbling banks of watercourses (but outside of the impact of running water).

Distribution: Hemiboreal-Cool Temperate, rather montane, East Asian taxon. In the peninsula it sparsely occurs around South Korea and should be more or less common in North Korea, but we have not seen any evidence on this point. The distribution of the variety is poorly understood. It seems to be a more or less common taxon in the northern half of Japan (where it is known under the name 'var. ovicalyx'). It is also known from Chinese Anhui, Hubei, Liaoning and Yunnan (Bakalin, 2014a) and the southern part of the Russian Far East.

Comments: The variety was described to replace an incorrect name that had been used for a long time, i.e., 'var. ovicalyx', which as a result of type studies is not differentiable from var. infusca (Bakalin, 2014a, 2014b). The variety probably represents a derivative of var. infusca formed under drier growing conditions and being different from the latter in leaves suborbicular or nearly so, commonly distant and more plane (never distinctly canaliculate, although sometimes concave), versus contiguous to subimbricate, lingulate-suborbicular leaves that are mostly distinctly concave-canaliculate.

6. Plectocolea kurilensis (Bakalin) Bakalin \& Vilnet, Bryologist 115: 577, 2012. Plectocolea flagellata var. kurilensis Bakalin, Arctoa 18: 90, 2009 [2010].

Korean name: Koo-ril-mang-ul-i-kki (쿠릴망울이끼).

Ecology: Meso-hygrophyte to hygrophyte acido- to neutrophilic taxon. The ecology of the species closely resembles that of $P$. infusca var. infusca with the differences in absence (or, at least, rarity) of $P$. kurilensis in man-made habitats and a tendency to occupy more wet habitats. Basically, it is the species of cold to warm temperate forests, although sometimes occurring also in mixed Manchurian forests or spreading southward to evergreen subtropical communities (as in southern Kyushu). P. kurilensis occupies partly shaded moist stones and cliffs along streams under the occasional (but never constant) impact of running water.

Distribution: Temperate East-Asian taxon, with known area covering the southern flank of the Russian Far East, Japan and the Korean Peninsula. It is not yet recorded from China and it is hardly possible it will be found there, due to the continental climatic conditions in China's northeast provinces (Heilongjiang, Jilin, Liaoning) that is in contrast with the distribution of the species in areas under the strong impact of wet air masses coming of the Pacific. In Korea it is known from Jeju-do only but should be distributed much more widely.

Comments: The taxon may be easily confused with Plectocolea infusca var. infusca, the distinctions from which are discussed under the latter. On the other hand, large plants from the southern tips of the area may be confused with $P$. rosulans. In the latter case, attention should be paid to rhizoid color and their distribution. P. rosulans is characterized by purple (rarely with admixture of colorless), rigid rhizoids, united in well-developed shoots (at least in their upper parts) into distinct narrow fascicles decurrent down along the stem, versus soft and colorless to purplish rhizoids with a rare admixture of purple ones, variously spreading, but never united into narrow distinct fascicles decurrent down the stem along its ventral side. Another feature present in the majority of forms of $P$. rosulans are slightly convex and recurved leaves-a feature never observed in $P$. kurilensis. Confusion also seems possible with young and prostrate phases of $P$. radicellosa, discussed under the latter taxon. Plectocolea horikowana Amakawa - is the southern species, seems to be restricted to southern Japan, is somewhat similar to the present taxon, although easily differs in biconcentric oil bodies (one large central eye), and somewhat convex leaves in well-developed shoots. This species was mentioned in dataset by Bakalin and Vilnet (2012), based on the accession from South Korea (South Korea: Cholla-pukdo Prov., Bakalin V., 112889 (KPABG)), but that report of this species is actually based on misidentification of weak modification of Plectocolea virgata. Later the same species was mentioned in Bakalin et al. (2014) based on the same mistaken identification. Actually, this taxon is not known in South Korea.

7. Plectocolea ovalifolia (Amakawa) Bakalin \& Vilnet, Bryologist 115: 579, 2012 (Fig. 7). Plectocolea infusca var. ovalifolia Amakawa, J. Jap. Bot. 34: 115, 1959; Jungermannia infusca var. ovalifolia (Amakawa) Amakawa, J. Hattori Bot. Lab. 22: 33, 1960.

Korean name: Nu-un-keun-mang-ul-i-kki (누운큰망울이끼).

Ecology: The species occurs mostly in montane coniferous forests, rarely descending to mixed coniferous-broadleaved forests. By habitat requirement it is an acidophilic mesohygrophyte, occupying fine mineral soils along streams in partially shaded conditions. 


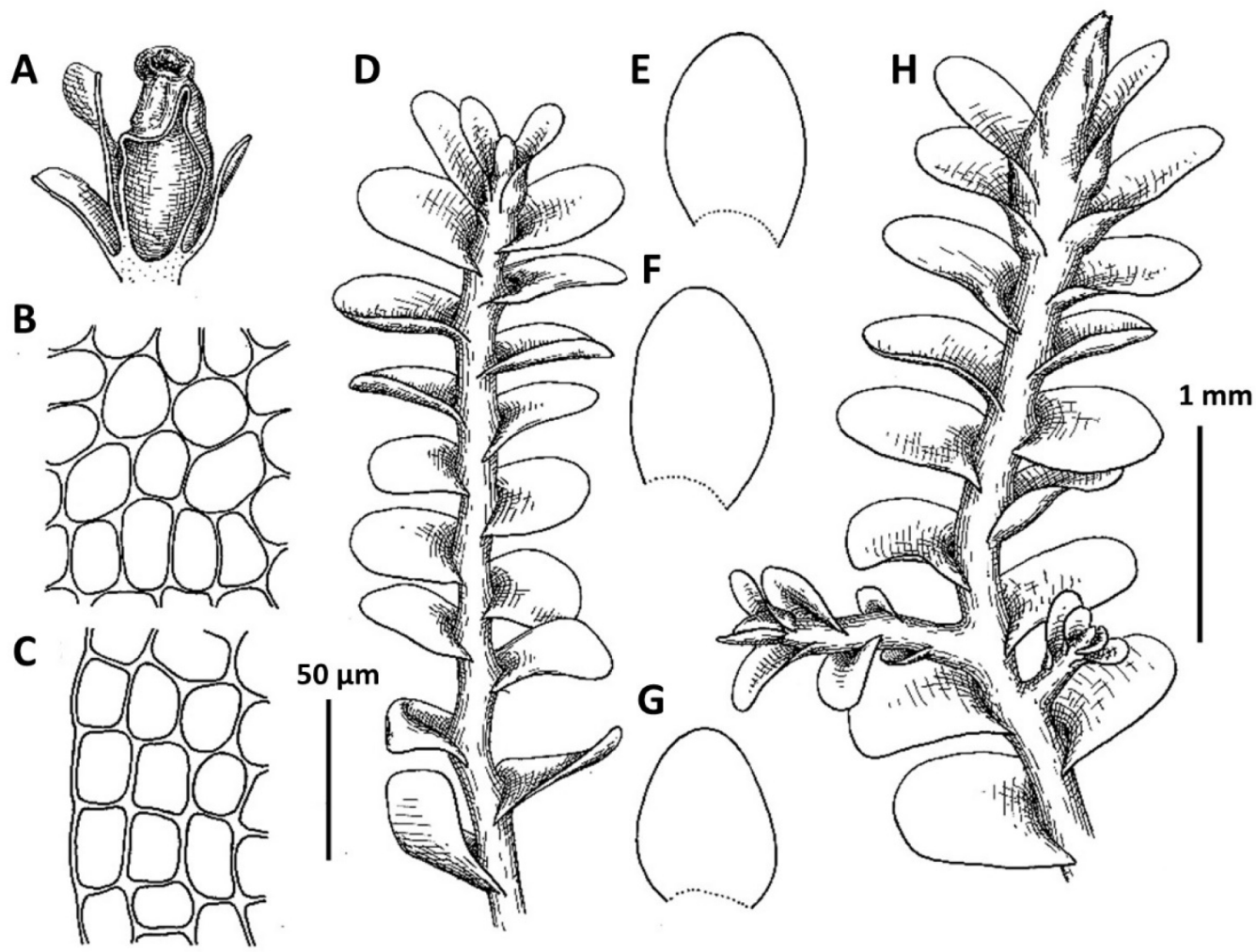

Fig. 7. Plectocolea ovalifolia (Amakawa) Bakalin \& Vilnet. A. Perianth longitudinal section. B. Midleaf cells. C. Cells along leaf margin. D. Sterile branch. E-G. Leaves. H. Perianthous branch (from Choi 8281). Scale bars = $1 \mathrm{~mm}(\mathrm{~A}, \mathrm{D}-\mathrm{H}), 50 \mu \mathrm{m}$ (B, C).

Distribution: Boreal montane East Asian species, sparsely distributed in the southern part of the Russian Far East (only its insular-peninsular areas), mountainous areas of Japan and a few localities in the Korean Peninsula, everywhere under the strong influence of Pacific air masses. Recorded from Jeju-do, Chungcheongbuk-do, and Gyeongsangnam-do (Yamada and Choe, 1997), with the report from Jeju-do looking doubtful. We confirmed it from Gangwon-do, Gyeongsangbuk-do, Gyeongsangnam-do, Jeollabuk-do, and Jeollanam-do.

Comments: This is an infrequent taxon occupying in distribution and, in a manner also in morphology, an intermediate position between Arcto-Boreal Montane CircumNorth Pacific Solenostoma obscurum and temperate East Asian Plectocolea infusca. It may be confused with both and is discussed under the latter names.

8. Plectocolea radicellosa (Mitt.) Mitt., Trans. Linn. Soc. London, Bot. 3: 196, 1891 (Figs. 8, 20K, L). Solenostoma radicellosum Mitt., J. Proc. Linn. Soc., Bot. 8: 156, 1865; Jungermannia radicellosa (Mitt.) Steph., Bull. Herb. Boissier, sér. 2, 1: 513, 1901.

Korean name: Keun-ip-mang-ul-i-kki (큰잎망울이끼).
Ecology: Acidophilic (to neutro-tolerate) hygrophyte, occurring in the lowland of subtropical to warm temperate forests with evergreen trees dominant. It occupies partially shaded to nearly open moist to wet cliffs and crumbling clayish banks along streams and rivers, mostly forming pure mats.

Distribution: Warm temperate-northern subtropical Japanese-Korean species. Within Japan it sparsely occurs in the southern half (southern Honshu, Shikoku, Kyushu). In Korea it has been recorded only from Jeju-do Island (Yamada and Choe, 1997) and was re-collected there by us several times. In addition, we found it in Chungcheongnam-do.

Comments: This beautiful warm temperate species is easily recognized when well-developed due to two peculiar features that differentiated it from the other known species of Plectocolea: (1) large granulate oil-bodies with (1)2-5 'eyes' (this very peculiar type of oil body is also present among regional taxa in $P$. comata, where, however the oil bodies are brown, but never gray, and frequently have more than 4-5 'eyes' per oil body), (2) rhizoids in distinct thick fascicles decurrent down along the ventral side of stem, colorless to brownish in color and originating as thick fascicles near postical leaf bases and immediately uniting with the central 
A
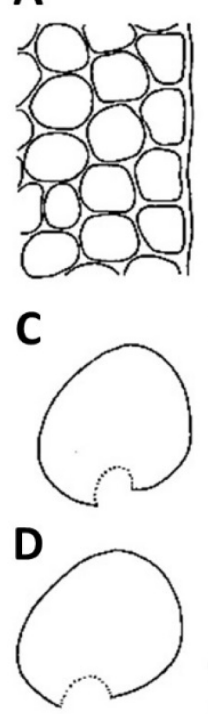

E

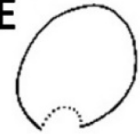

B

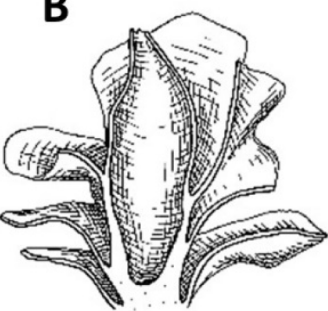

F
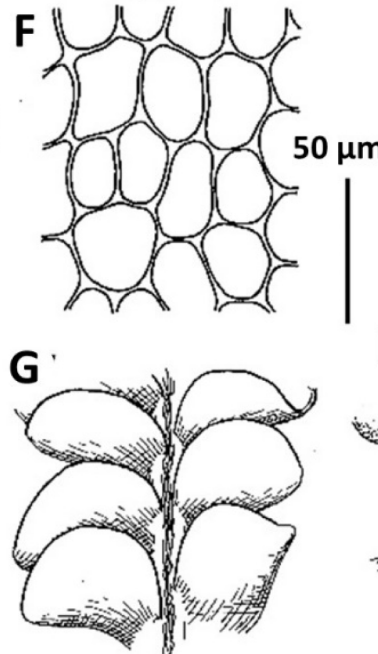

H

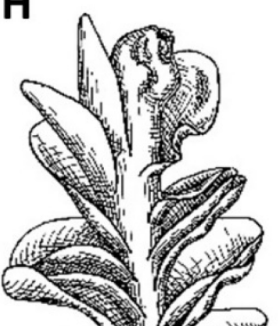

.

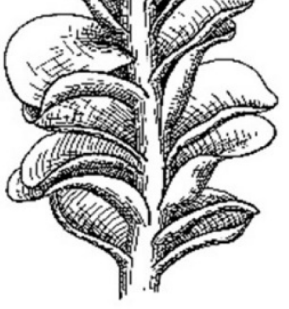

L

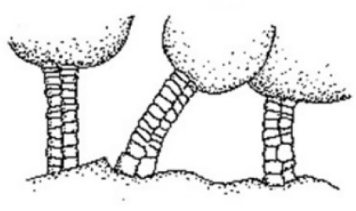

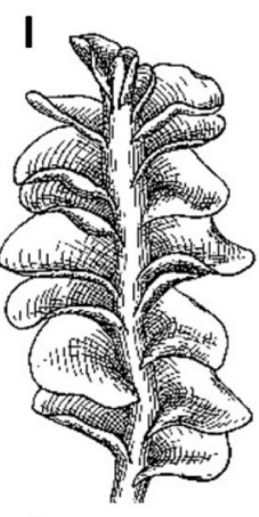

J

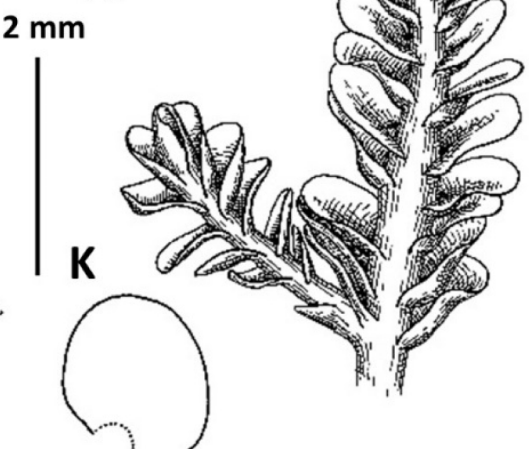

Fig. 8. Plectocolea radicellosa (Mitt.) Mitt. A. Cells along leaf margin. B. Perianth longitudinal section. C-E, K. Leaves. F. Midleaf cells. G. Branch fragment, ventral view. H. Perianthous branch. I. Sterile branch. J. Male branch. L. Antheridia (from Choi 112265). Scale bars $=50 \mu \mathrm{m}(\mathrm{A}, \mathrm{F}, \mathrm{L}), 2 \mathrm{~mm}(\mathrm{~B}-\mathrm{E}, \mathrm{G}-\mathrm{K})$.

bundle. However, when growing on crumbling riversides and forming patches partly to fully destroyed by running water in spring flood (a situation frequently observed in Jeju-do Island), the species produces prostrate forms, closely attached by rhizoids to the substratum and then rhizoids acquire a purplish to purple pigmentation and do not form distinct fascicles. Any variations between typical semi-erect forms and prostrate ones may be observed within the same locality. In the latter case the differentiation of the species may offer considerable difficulties in respect to Plectocolea kurilensis and even $P$. infusca. The best way to differentiate these species is to study them in a fresh condition (and then find oil-bodies with eyes in $P$. radicellosa). However, after material has been dried, and the oil-body feature is not available, differentiation may be unclear. The main feature in that case is the rhizoid origin area that is mostly near postical leaf bases in $P$. radicellosa.

9. Plectocolea rosulans (Steph.) S. Hatt., Bull. Tokyo Sci. Mus. 11: 38, 1944 (Figs. 9, 20M). Nardia rosulans Steph., Bull. Herb. Boissier 5: 101, 1897; Jungermannia rosulans (Steph.) Steph., Bull. Herb. Boissier, sér. 2, 1: 501, 1901; Solenostoma rosulans
(Steph.) Váňa \& D. G. Long, Nova Hedwigia 89: 507, 2009.

Korean name: Mang-ul-i-kki (망울이끼).

Ecology: Acidophilic to neutro-tolerant hygro- to hydrophyte, occupying moist to wet rocks along streams (also those under the continuous impact of running water) in partial shade, mostly forming pure patches, rarely occurring with slight admixtures of other hepatics. It occurs in broadleaved cool temperate to evergreen warm temperate lowland forests.

Distribution: South temperate - north subtropical JapaneseKorean species known in the southern half of the Japanese archipelago and the southern part of the Korean Peninsula.

Comments: This is a large and beautiful species that is easily recognized due to its distinct and narrow bundle of purple rhizoids decurrent down the stem along its ventral side and by its generally ascending growth form. Confusion seems to be possible in two ways: on the one hand normally developed shoots of Plectocolea rosulans may be mistaken with large and well-developed forms of $P$. kurilensis (distinctions discussed under the latter); on the other hand weak shoots of P. rosulans (plant size in both species merge) may be mistaken 

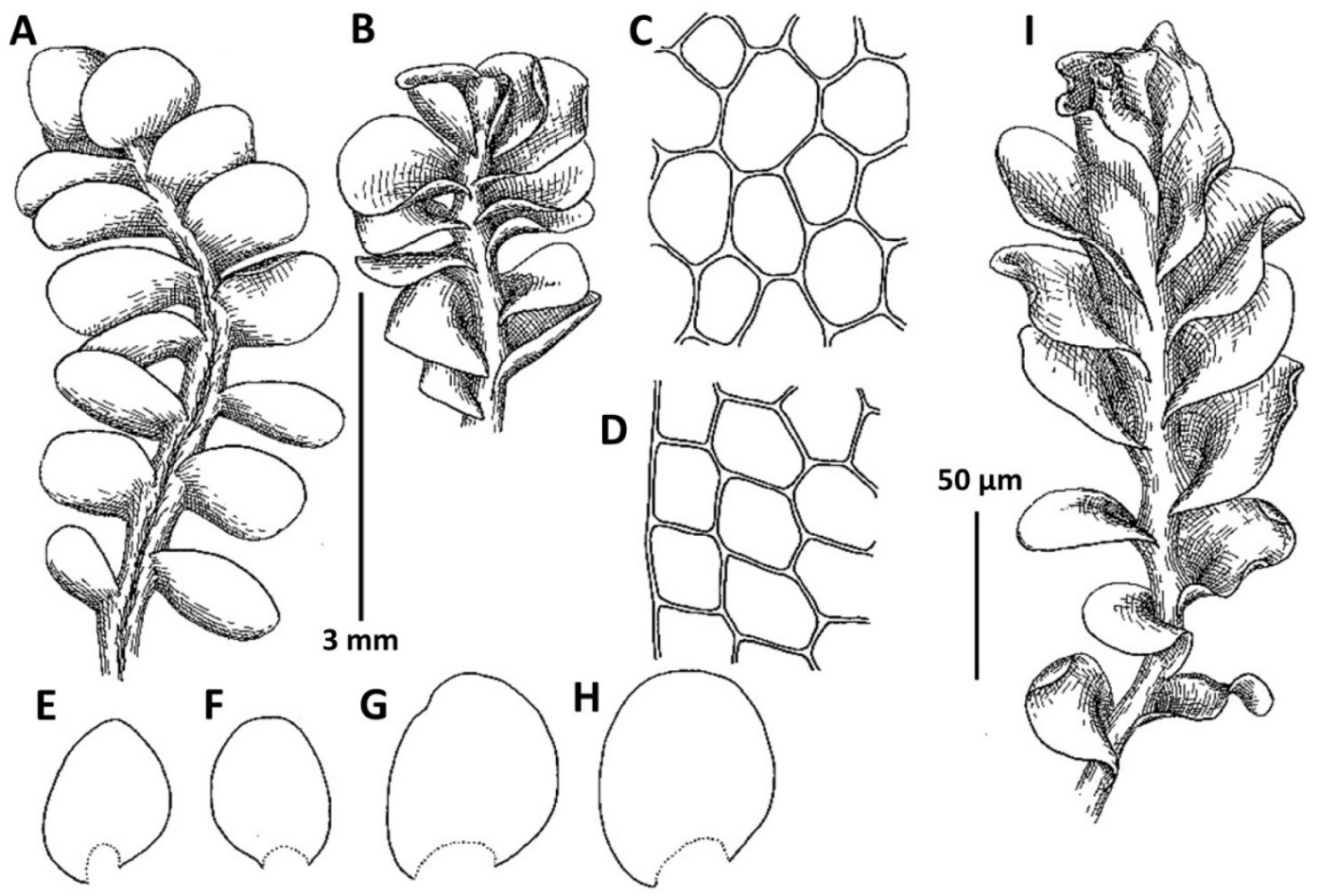

Fig. 9. Plectocolea rosulans (Steph.) S. Hatt. A. Sterile branch, bentral view. B. Sterile branch. C. Midleaf cells. D. Cells along leaf margin. E-H. Leaves. I. Perianthous branch (A-H from Choi 4107, I from Choi 8821). Scale bars = $3 \mathrm{~mm}$ (A, B, E-I), $50 \mu \mathrm{m}$ (C, D).

for $P$. erecta. In the latter case the two taxa may be differentiated by: (1) primarily erect growth form of $P$. erecta versus prostrate (in weak forms) growth of P. rosulans, (2) stems with a more or less distinct differentiation into three strata in cross section in P. erecta, versus composed of monomorphic cells in P. rosulans, (3) absence of ventral leafless geotropic stolons in $P$. erecta, versus their more or less common presence in $P$. rosulans. Rarely this species may be mistaken with $P$. virgata, the distinctions given under the latter.

10. Plectocolea torticalyx (Steph.) S. Hatt., Bull. Tokyo Sci. Mus. 11: 38, 1944 (Fig. 10A-I). Jungermannia torticalyx Steph., Sp. Hepat. 6: 94, 1917; Solenostoma torticalyx (Steph.) C. Gao, Fl. Hepat. Chin. Boreali-Orient. 69, 1981.

Korean name: Bo-ra-mang-ul-i-kki (보라망울이끼).

Ecology: Acidophilic hygro- to hydrophyte. The species known is in Korea from fine soils on streambanks in partially shaded habitats in broadleaved deciduous forests.

Distribution: Temperate-subtropical East Asian species, sparsely distributed in Japan (becoming more frequent southward), known as a rarity in Korea (Jeollabuk-do, Jeollanamdo) and reported from Chinese Guangdong and Liaoning.
Comments: Plectocolea torticalyx known in Korea from two specimens, both of which are somewhat smaller than the type (Bakalin 2014b) and probably represent one of the northernmost dwarf forms of the species. Confusion of $P$. torticalyx is possible with $P$. grossitexta, previously regarded as a synonym of the former; the distinctions between them are given under the latter. The lax and soft plant habit and purple rigid rhizoids should preclude misidentification with other Plectocolea species in Korea proper.

11. Plectocolea truncata (Nees) Herzog, Trans. Brit. Bryol. Soc. 1: 281, 1950 (Figs. 11, 12A-C). Jungermannia truncata Nees, Enum. Pl. Crypt. Jav. 29, 1830.

Korean name: Deul-mang-ul-i-kki (들망울이끼).

Ecology: Acido- to neutrophilic mesophyte, growing over open or (rarer) partially shaded fine mineral soil and cliffs, including cliff crevices along seashores in full sun. It is widespread in man-made habitats (roadsides, trails, etc.) but also occurs on crumbling slopes to water courses at some distance from running water. It is limited in distribution in the southern flank of Korea proper, where it occurs in lowlands covered by temperate broadleaved forests enriched by some 


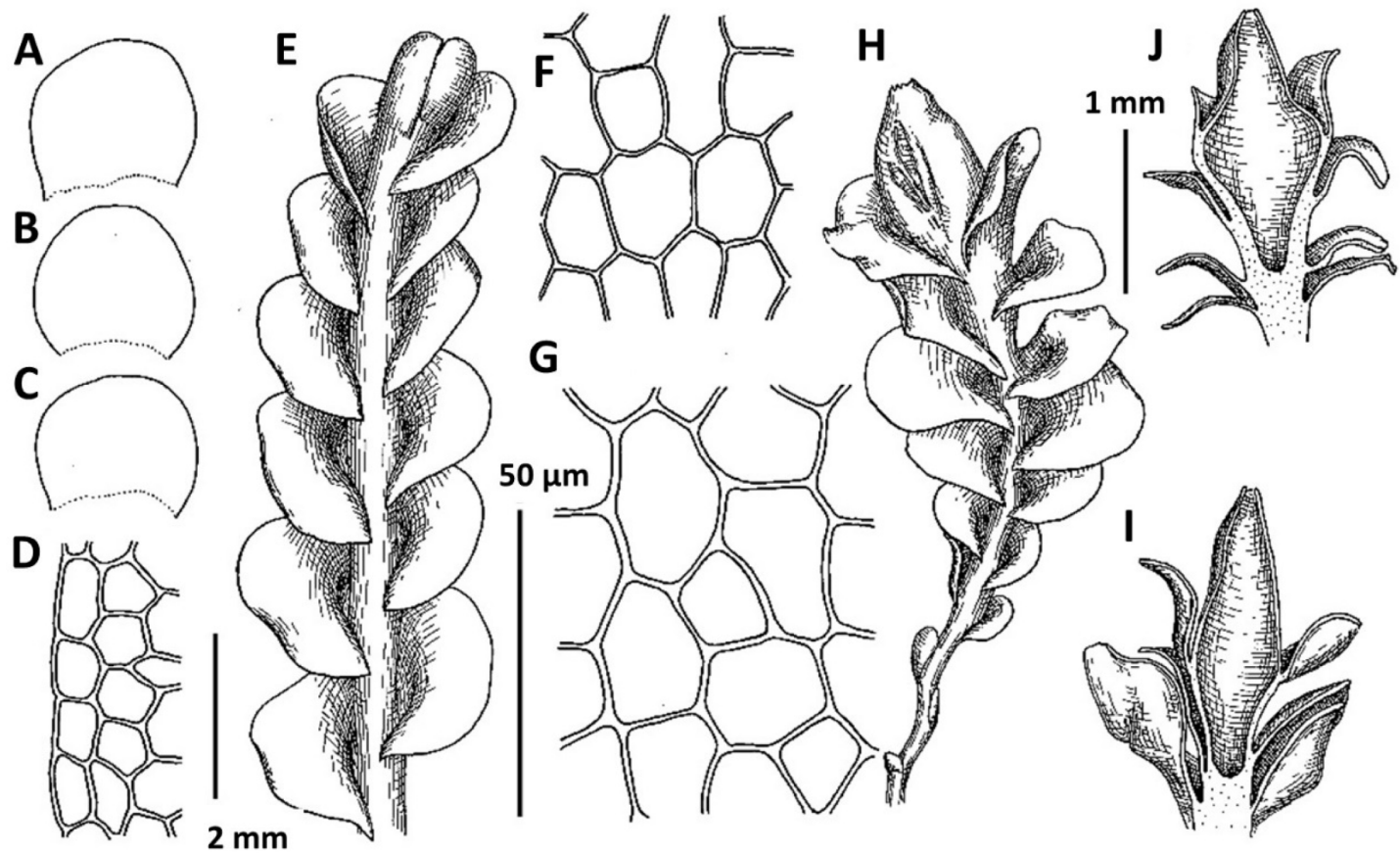

Fig. 10. Plectocolea torticalyx (Stephani) S. Hatt. A-I. A-C. Leaves. D. Cells along leaf margin. E. Sterile branch. F, G. Midleaf cells. H. Perianthous branch. I. Perianth longitudinal section (1-6 from Choi 6071; 7-9 from Choi 3093). Plectocolea virgata Mitt. J. - perianth longitude section (from Choi 111260). Scale bars $=2 \mathrm{~mm}(\mathrm{~A}-\mathrm{C}, \mathrm{E}, \mathrm{H}, \mathrm{I}), 1 \mathrm{~mm}(\mathrm{~J}), 50 \mu \mathrm{m}(\mathrm{D}, \mathrm{F}, \mathrm{G})$.

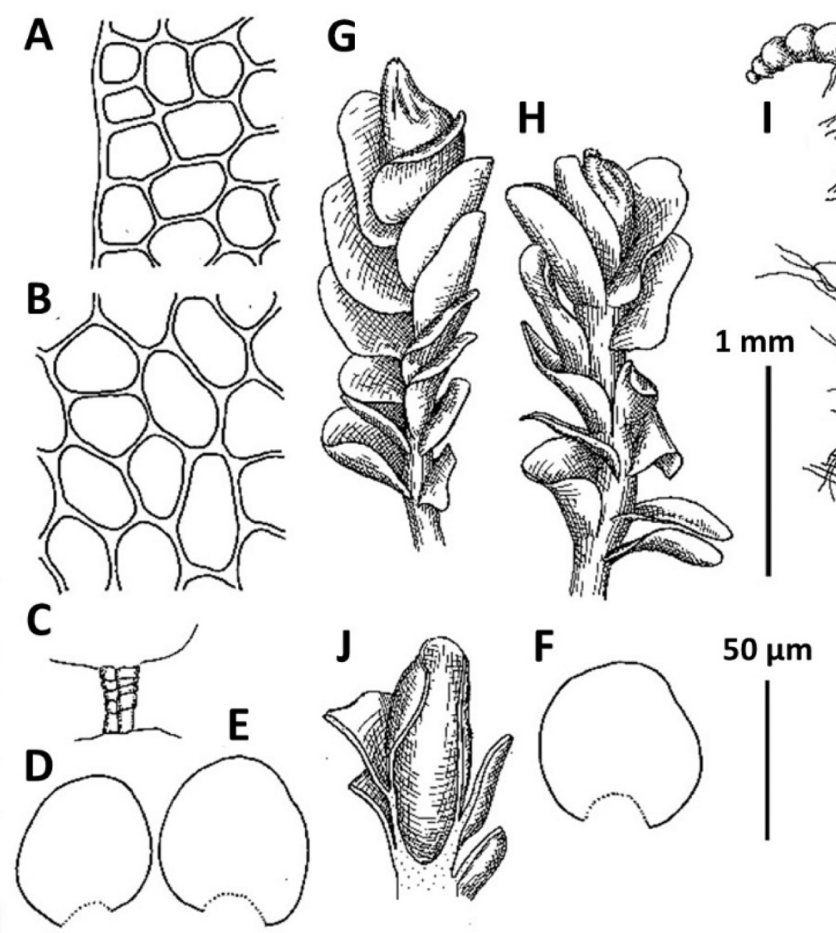

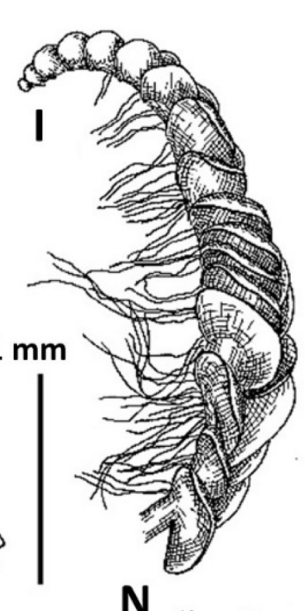

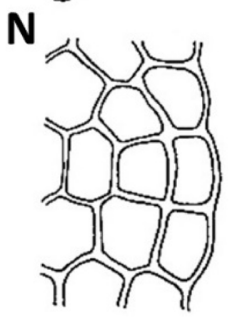

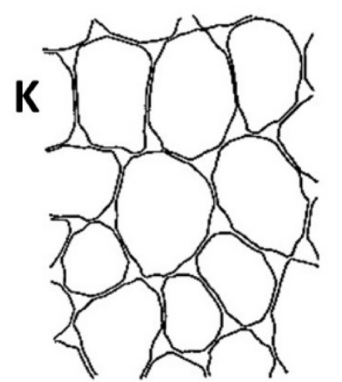
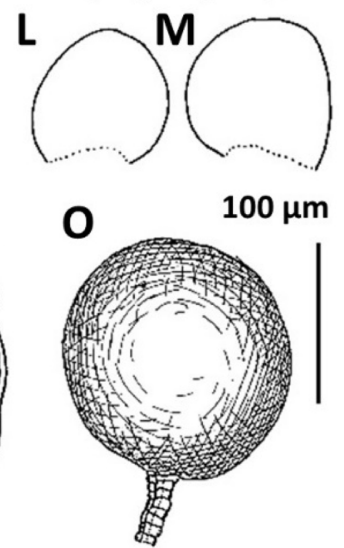

Fig. 11. Plectocolea truncata (Nees) Herzog. A, N. Cells along leaf margin. B, K. Midleaf cells. C, O. Antheridia. D-F, L, M. Leaves. G, H. Perianthous plants. I. Male branch. J. Perianth longitudinal section (A-I from Choi 8878; J-N from Choi 8059). Scale bars $=50 \mu \mathrm{m}$ (A, B, K, $\mathrm{N}), 100 \mu \mathrm{m}(\mathrm{C}, \mathrm{O}), 1 \mathrm{~mm}(\mathrm{D}-\mathrm{J}, \mathrm{L}, \mathrm{M})$. 
evergreen shrubs of mainly of subtropical distribution.

Distribution: Probably broadly tropical-subtropical East Asian. The distribution of the species is poorly understood because of the 'collective' nature of this taxon for a long time when many different taxa (e.g., Plectocolea granulata, P. shinii, etc.) were placed in this hardly understandable complex. In China it is recorded in Yunnan, Huizhou, Hainan, and Taiwan, but must be more widely distributed. In Japan its distribution starts from middle Honshu and then becomes more frequent southward (including Ryukyu, but probably completely replaced by Plectocolea boninensis in Bonin). Southward it widely spreads to Indo-China where it is replaced by $P$. setulosa Herzog and other morphologically intergrading taxa (relationships never tested genetically). It is recorded for Gyeongsangbuk-do and Gyeongsangnam-do (Yamada and Choe, 1997) and found by us in Chungcheongnam-do and Jeju-do.

Comments: Plectocolea truncata, similar to P. comata, reflects southern relationships in the Korean flora and occurs in southernmost parts of the study area (although being much more common than $P$. comata that is quite sparse even in the subtropics). Commonly it is an easily identifiable taxon due to the dull plant color, colorless rhizoids, thickened leaf marginal cell walls, with cells smaller along margin than in the midleaf. It is the only species of the genus we were able to observe growing on full-sun cliffs in the southernmost flank of the peninsula. However rarely this species may produce rather leptodermous modifications with hardly thickened cell walls along the leaf margins and then produces pink to purplish rhizoids. These modifications maybe mistaken for northern Metasolenostoma ochotense (never found in the southern tips of the peninsula), from which Plectocolea truncata differs in typical 'plectocoleoid' perianth (versus nearly 'solenostomoid') and truncate to shallowly emarginate leaf apices (versus apex of sterile leaves rounded).

12. Plectocolea virgata Mitt., Trans. Linn. Soc. London, Bot. 3: 197, 1891 (Figs. 10J, 12D-O, 20N-P). Jungermannia virgata (Mitt.) Steph., Bull. Herb. Boissier, sér. 2, 1: 504, 1901.

Korean name: Bae-ru-ka-mang-ul-i-kki (배루카망울이끼).

Ecology: Acidophilic hygrophyte occupying stones and cliffs along streams, in partial shade, never occurring on fine crumbling soils. Within Korea the species occurs in south temperate deciduous (enriched by evergreen shrubs) to evergreen forests in the southern flank of the area treated and does not become montane.

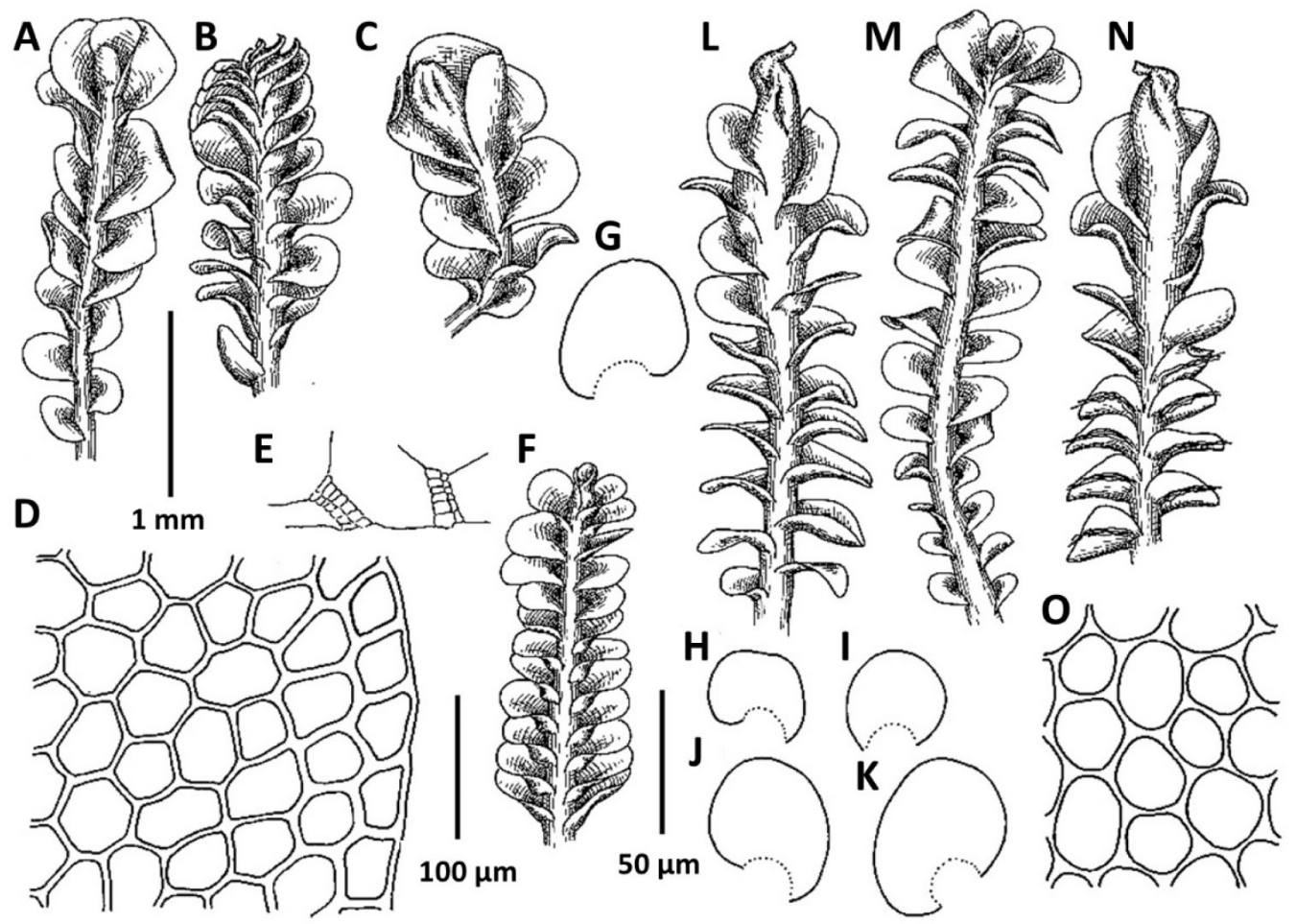

Fig. 12. Plectocolea truncata (Nees) Herzog. A-C. A. Sterile branch. B. Male branch. C. Perianthous branch (from Choi 8059). Plectocolea virgata Mitt. D-O. D. Cells along leaf margin. E. Antheridial stalks. F. Male branch. G-K. Leaves. L, N. Perianthous plants. M. Sterile branch. O. Midleaf cells (from Choi 111260). Scale bars $=1 \mathrm{~mm}(\mathrm{~A}-\mathrm{C}, \mathrm{F}-\mathrm{N}), 50 \mu \mathrm{m}(\mathrm{D}, \mathrm{O}), 100 \mu \mathrm{m}(\mathrm{E})$. 
Distribution: Montane in temperate-subtropical East Asian, with distribution limited by the Japanese Archipelago (where locally abundant), solitarily known in Chinese Zhejiang and Taiwan and the southern flank of Korea (Jeju-do, also recorded from Gyeongsangnam-do) (Yamada and Choe, 1997). The report of the species for the Kurils (Bakalin et al., 2009) is based on the misidentification of poorly developed phases of other species (Bakalin, 2014a).

Comments: This taxon is commonly easy to identify due to its narrow shoots, distinct rhizoids in fascicles decurrent down along the ventral side of stem, commonly thickened cell walls along leaf margins and subtransversely inserted erectspreading leaves. Some difficulties may be possible with delimitation of the taxon from Plectocolea erecta and differential features are discussed under the latter. The prostrate forms of $P$. virgata (formed in shady conditions) may also be mistaken with dwarf forms of $P$. rosulans. The best feature in this case is oil-body characters. Oil-bodies in P. virgata are entirely spherical, nearly smooth or with a surface that looks like crumpled paper, whereas the oil-bodies in P. rosulans are always granulate, spherical to elliptic, and more than two in number. Other features, including thickened cell walls along leaf margins and a finely verrucose cuticle, may not always work (because prostrate forms and forms from overly wet habitats in $P$. virgata mostly have thin-walled cell walls along leaf margins and a smooth cuticle). The species was never collected with sporophytes in Korean Peninsula. The unispiral elaters are very distinctive and may help to recognize the species (Bakalin, 2016).

III. Protosolenostoma (Amakawa) Bakalin \& Vilnet, Bot. Pacif. 3: 14, 2014. Jungermannia sect. Protosolenostoma Amakawa, J. Hattori Bot. Lab. 22: 55, 1960.

Korean name: Bang-chu-hyeong-mang-ul-i-kki-sok (방추 형망울이끼속).

Monotypic genus described mostly based on genetic evidence (Bakalin et al., 2014).

1. Protosolenostoma fusiforme (Steph.) Vilnet \& Bakalin, Bot. Pacif. 3: 14, 2014 (Figs. 13, 20Q-T). Nardia fusiformis Steph., Bull. Herb. Boissier 5: 99-100, 1897; Solenostoma fusiforme (Steph.) R. M. Schust., Hepat. Anthocerotae N. Amer. 2: 944, 1969.

Solenostoma koreanum Steph., Sp. Hepat. 6: 81, 1917. TYPE: Korea. Jeju, U. Fauire 236 (holotype: G!)

Korean name: Bang-chu-hyeong-mang-ul-i-kki (방추형 망울이끼).

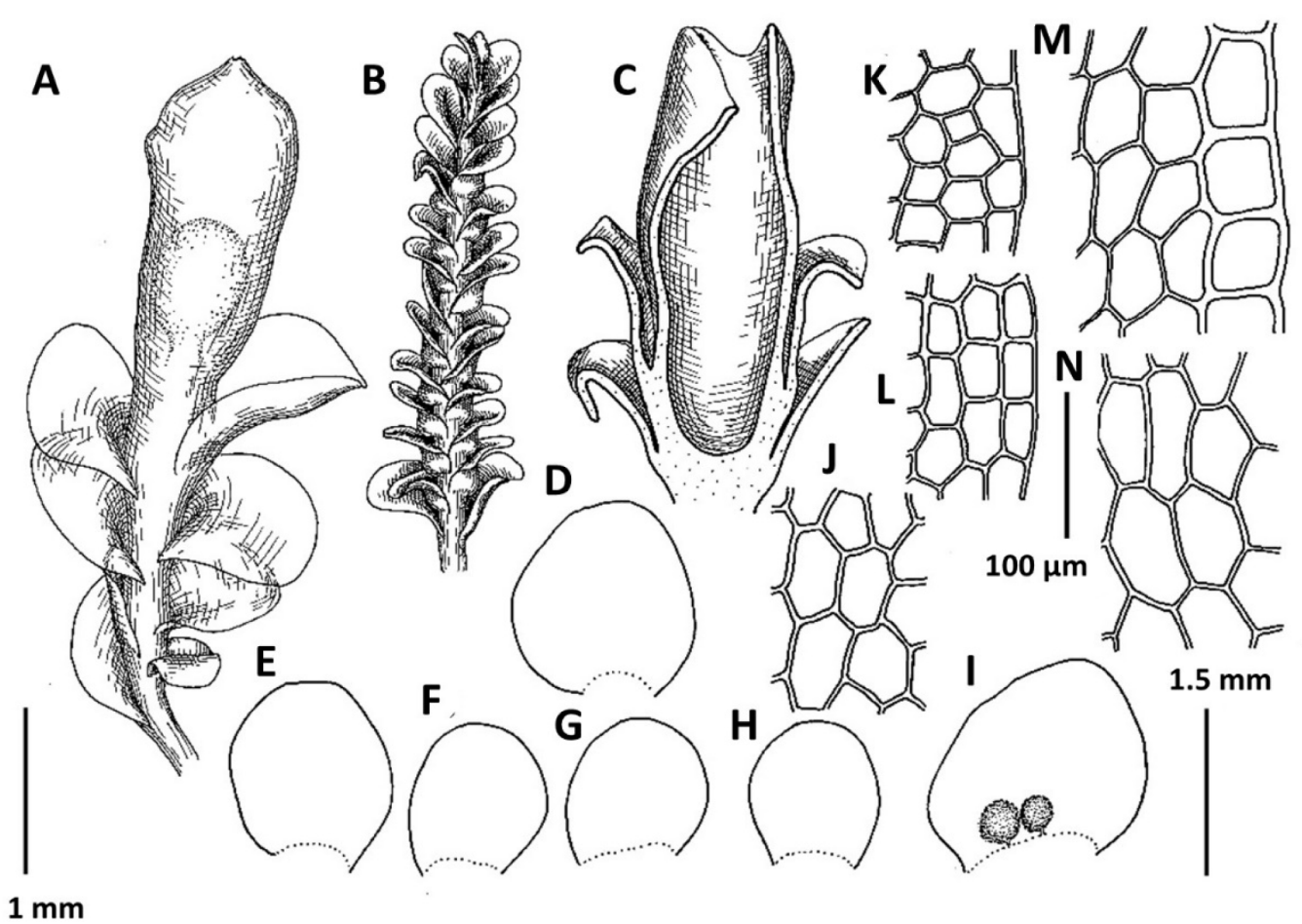

Fig. 13. Protosolenostoma fusiforme (Steph.) Vilnet \& Bakalin. A. Perianthous branch. B. Male branch. C. Perianth longitudinal section. D-H. Leaves. I. Male bract. J, N. Midleaf cells. K-M. Cells along leaf margin (from Choi 111482). Scale bars = $1 \mathrm{~mm}(\mathrm{~A}-\mathrm{H}), 1.5 \mathrm{~mm}$ (I), $100 \mu \mathrm{m}$ (J-N). 
Ecology: Acidophilic to neutron-tolerant hygrophyte, known from many specimens but mostly from higher elevation in Halla Mt. and vicinity. As well as in Japan, the species is distributed in areas with evidence of extant or extinct volcanism in subalpine to alpine belts. The species grows in rather open to partially shaded places on moist bare mineral soil and is commonly associated with Nardia assamica.

Distribution: Temperate Japanese-Korean endemic, distributed in areas with evidence of extant (not present in Korea) or extinct volcanism. Recorded from Jeju-do (Yamada and Choe, 1997) and also found by us from Jeollabuk-do and Jeollanam-do.

Comments: The type species of Jungermannia sect. Protosolenostoma (elevated to generic rank by Bakalin et al., 2014) is Solenostoma koreanum (synonymized with Jungermannia fusiforme described from Japan). This is a species of volcanically modified habitats across its worldwide area. Protosolenostoma fusiforme has distinct morphological relationships to Metasolenostoma and especially to $M$. ochotense (also in areas of volcanically modified habitats) with which it may be easily mistaken. However, Protosolenostoma differs from $M$. ochotense by quite large midleaf cells (mostly exceeding $40 \times 35 \mu \mathrm{m}$ ) and by a conspicuous leaf rim composed of cells larger than in midleaf (up to $100 \mu \mathrm{m}$ along margin!) and thick-walled.

IV. Solenostoma Mitt., J. Linn. Soc. Bot., 8: 51, 1865. Jungermannia subg. Solenostoma (Mitt.) Amakawa, J. Hattori Bot. Lab. 22: 53, 1960.

Korean name: Doong-keun-mang-ul-i-kki-sok (둥근망울 이끼속).

The main taxonomic diversity of the genus (that is in contrast with Plectocolea) is in the Sino-Himalaya and Hengduan Range (southwestern China). Ten species of the genus are recorded in Korea proper and are described below.

1. Solenostoma bilobum (Amakawa) Potemkin \& Nyushko, Pechen. Anthotser. Ross. 1: 286, 2009 (Figs. 14K-R, 20A). Plectocolea biloba Amakawa, J. Jap. Bot., 32: 216. f. 7, 1957.

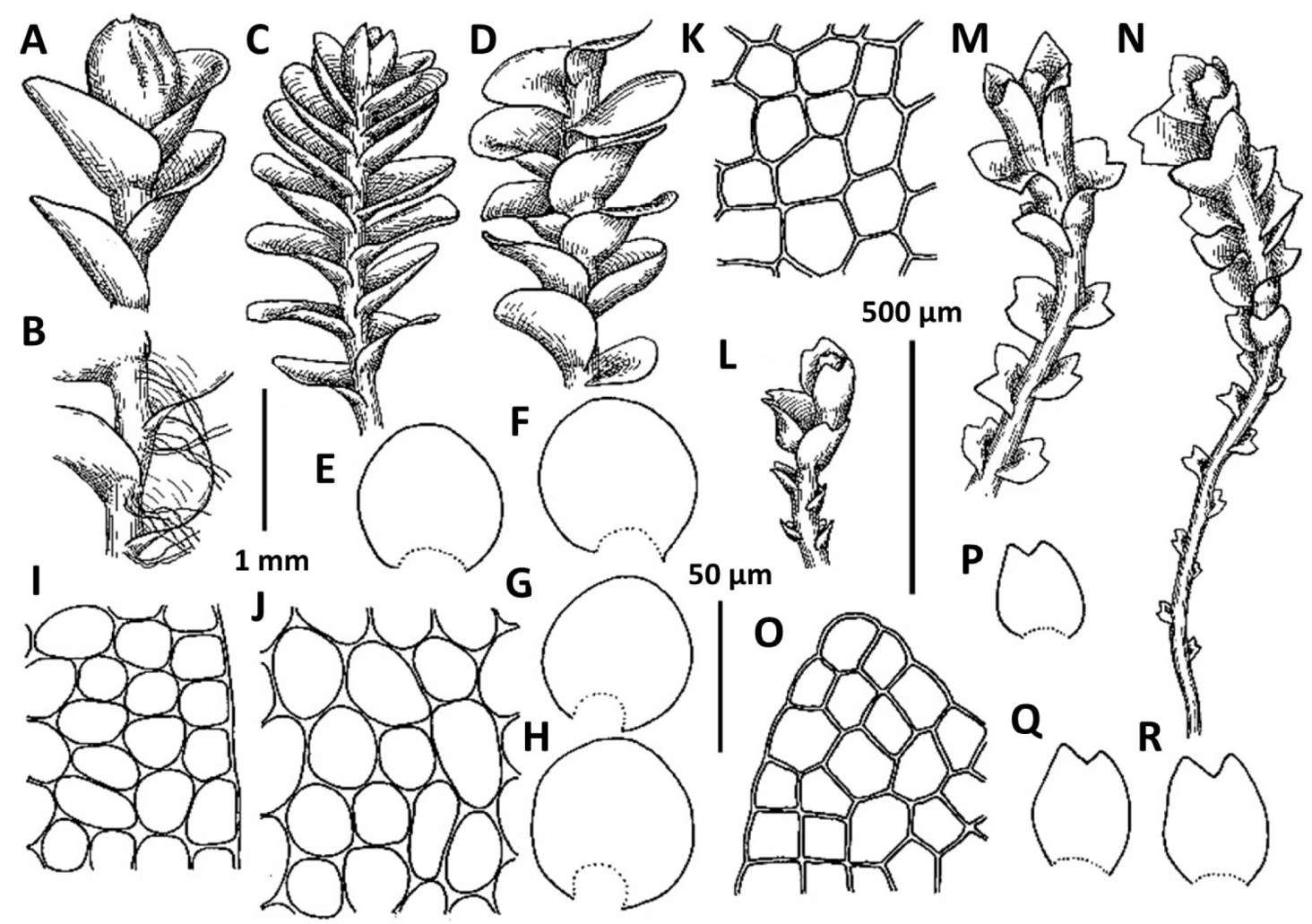

Fig. 14. Solenostoma cyclops (S. Hatt.) R. M. Schust. A-J. A. Perianthous branch apex. B. Branch fragment, ventral view. C. Sterile branch. D. Branch fragment. E-H. Leaves. I. Cells along leaf margin. J. Midleaf cells (from Choi 7279). Solenostoma bilobum (Amakawa) Potemkin \& Nyushko. K-R. K. Midleaf cells. L. Male branch. M. Perianthous branch. N. Sterile branch. O. Leaf lobe apex. P-R. Leaves (from Choi 3762). Scale bars $=1 \mathrm{~mm}(\mathrm{~A}-\mathrm{H}), 50 \mu \mathrm{m}(\mathrm{I}-\mathrm{K}, \mathrm{O}), 500 \mu \mathrm{m}(\mathrm{L}-\mathrm{N}, \mathrm{P}-\mathrm{R})$. 
Jungermannia cephalozioides Amakawa, J. Hattori Bot. Lab., 22: 41, 1960.

Korean name: Gal-lae-mang-ul-i-kki (갈래망울이끼).

Ecology: Acidophilic hygrophyte, occupying moist stones and cliffs in partial shade, in broadleaved deciduous to evergreen forests at low to middle elevations.

Distribution: Kurils-Japanese-Korean endemic, also known in southernmost Kurils. Throughout its area it is very sparsely distributed, although sometimes probably overlooked due to its small size and occurrence in small quantities. In the Korean Peninsula known only in its southern flank, from Gyeongsangnam-do, Jeju-do and Jeollabuk-do.

Comments: Within the Solenostoma-Plectocolea complex this species is very distinctive due to bilobed leaves, tiny size of plants and tall perigynium. The only relative worldwide is $S$. emarginatum (with which the species was misidentified before (Ahn, 2011), that differs from S. bilobum in larger size (wider $1 \mathrm{~mm}$ wide), emarginate (not deeply bilobed) leaves with rounded lobe apices and distinct differentiation of the stem in the cross section into hyaloderm, scleroderm and inner tissue.

2. Solenostoma cyclops (S. Hatt.) R. M. Schust., Hepat. Anthocerotae N. Amer. 2: 945, 1969 (Fig. 14A-J). Jungermannia cyclops S. Hatt., J. Hattori Bot. Lab. 3: 5, 1950.

Korean name: Ji-ri-mang-ul-i-kki (지리망울이끼).

Ecology: Acidophilic hygrophyte, occupying moist mineral soils near streams (under rare and temporary impact of running water) in partial shade.

Distribution: Japanese-Korean endemic taxon sparsely occurs in southern half of Japan (but common in upper elevations of Yakushima Island) and the southernmost tip of Korea proper (Jeollabuk-do).

Specimens examined: Jeollabuk-do, Jirisan Mt., elev. 860 m, Choi 7279 (JNU).

Comments: The distinct features of the species include the combination of erect growth form, typical 'solenostomoid' perianth, and purple (or at least with distinct admixture of purple) rhizoids. The species has morphological relations to Solenostoma purpuratum var. koponenii from which it differs from in rhizoid color (always with admixture of purple colored ones, versus colorless to brownish), non-fasciculate rhizoids (versus distinctly fasciculate) and relatively larger plant size (mostly wider $1.2 \mathrm{~mm}$, versus mostly narrower than $1.2 \mathrm{~mm}$ ).

3. Solenostoma faurianum (Beauverd) R. M. Schust., "fauriana" Hepat. Anthocerotae N. Amer. 2: 945, 1969.
Jungermannia fauriana Beauverd, Sp. Hepat. 6: 571, 1924.

Korean name: Ha-u-ri-mang-ul-i-kki (하우리망울이끼).

Comments: The story of this species began with confusion. Firstly, Stephani in the original description used a name for this taxon that was a later homonym: Jungermannia decurrens Steph. (Sp. Hepat. 6: 85. 1917., auct. non Jungermannia decurrens Desv., Observ. Pl. Angers 20, 1818; non Jungermannia decurrens Reinw., Blume \& Nees, Nova Acta Phys.-Med. Acad. Caes. Leop.-Carol. Nat. Cur. 12: 206, 1825). Then Beauverd, who was editor of Species Hepaticarum, in his final appendix to the sixth volume, provided a nomen novum for Stephani's taxon (Jungermannia fauriana Beauverd, Sp. Hepat. 6: 571, 1924.).

Another confusing thing was that the locus classicus for the species was cited as "Japonia. Quelpart" (=Jeju-do Island) the citation can probably be explained because in the first half of the 20th century Korea was under Japanese suzerainty. Overlooking this fact (although it was correctly understood by Amakawa 1960), Hong (1962) recorded Jungermania fauriana as a species new for Korea. Hong (1962: 485) also provided an impossible habitat for the species as "bark of trees" and "accompanied with Ptilidium pulcherrimum" that suggests an obvious misidentification at the generic level, although his picture (1.c., fig. 24: k-p) fits Solenostoma faurianum well. Despite several attempts (especially considering the small size of the island), we were unable to find this species on Jeju-do Island. Therefore, if the label in Stephani's herbarium is not mistaken (e.g., Quelpart is not a mistake for Yakushima), the only record of this species in Korea proper is that published by Stephani from Jeju-do Island.

The type material of this species (from Jeju-do Island?) has been described and illustrated very recently by Bakalin (2014b). Because no additional material is available, we do not repeat that description again. Solenostoma faurianum seems to be a rather distinct species that is difficult to mistake with other Solenostoma species within area treated due to its large size, reddish color and few to absent purple rhizoids.

4. Solenostoma jirisanense Bakalin \& S. S. Choi, sp. nov. (Figs. 15A-K, 20U-W).-TYPE: Korea. Gyeongsangnam-do: Jirisan Mt., elev. 1,620 m, Choi 3747-3 (Holotype: JNU).

Korean name: Chil-seon-mang-ul-i-kki (칠선망울이끼).

Plants prostrate to ascending near apices, closely attached by rhizoids to the substratum or to other plants, brown to brownish, brown-green, rusty, red-brown and reddish brownish, with common and evident purple tint near perianth apices, 


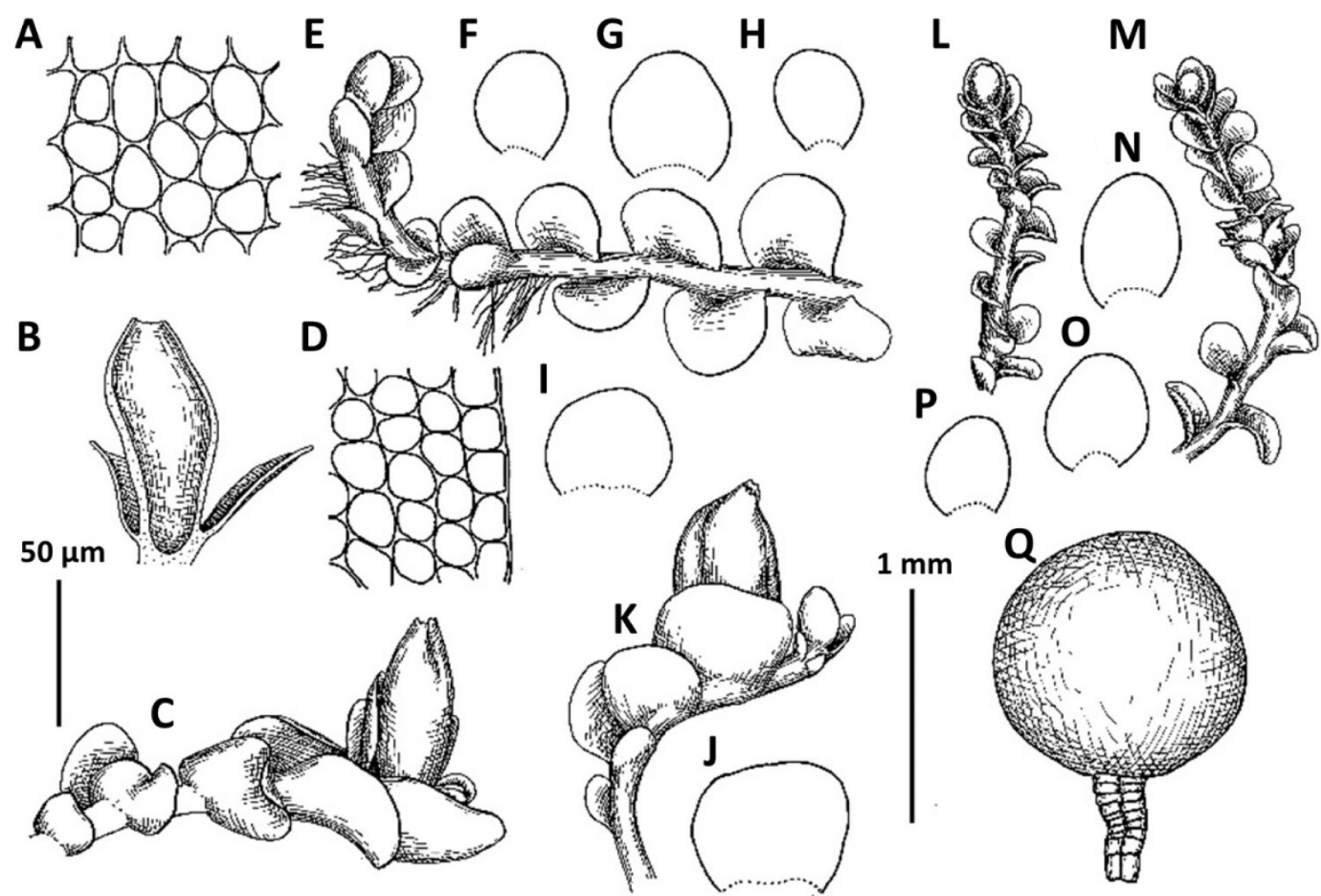

Fig. 15. Solenostoma jirisanense Bakalin \& S. S. Choi. A-J. A. Midleaf cells. B. Perianth longitudinal section. C, K. Perianthous branches. D. Cells along leaf margin. E. Sterile branch. F-I. Leaves. J. Female bract (from Choi 3747-3). Solenostoma minutissimum (Amakawa) Bakalin, Vilnet \& Furuki. L-Q. L, M. Sterile branches. N-P. Leaves. Q. Antheridium (from Choi 120745). Scale bars $=50 \mu \mathrm{m}(\mathrm{A}, \mathrm{D}, \mathrm{O}), 1 \mathrm{~mm}(\mathrm{~B}, \mathrm{C}$, E-P).

upper part of leaves or (sometimes) basal part of leaves, (350)500-1,200(1,300) $\mu \mathrm{m}$ wide and 7-20 mm long. Rhizoids dense, forming mat under stem or erect spreading in unclear fascicles or separated, colorless, brownish, pinkish to purplish (the last ones originated mostly from the stem near base of perianth). Stem slightly transversely elliptic in cross section, 150-250 $\mu \mathrm{m}$ wide, brownish, sometimes with more deeply colored ventral side, sparsely laterally (intercalary) or ventrally branched, almost always with ventral subfloral innovations (one per perianth). Leaves contiguous to distant, obliquely (40$50^{\circ}$ with axis) inserted, dorsally shortly (not more than $1 / 4$ of stem width) decurrent, ventrally subtransversely inserted, not decurrent, obliquely to erect spreading, obliquely oriented, loosely sheathing the stem in the base and deflexed above or slightly concave and not sheathing the stem, ovate to ovateorbicular, transversely elliptic and obliquely ovate-lingulate, $500-830 \times 500-1,000 \mu \mathrm{m}$. Midleaf cells $15-25 \times 12-20 \mu \mathrm{m}$, thin-walled, with moderate in size, slightly concave or slightly convex trigones, cuticle smooth; cells along margin 12-22 $\mu \mathrm{m}$, thin-walled, with slightly thickened or thin external wall, trigones moderate in size, mostly slightly convex; oil-bodies 6-10 per cell, mostly oblong, $5-9 \times 4-5 \mu \mathrm{m}$ to spherical $4-5$ $\mu \mathrm{m}$ in diameter, $10 \%$ (rarer up to $50 \%$ ) of oil-bodies with central eye (biconcentric). Dioicous? (Androecia not known). Perianth terminal, with one subfloral ventral innovation fertilized again after not less than 20 pairs of sterile leaves, exerted for $2 / 3-4 / 5$ of its length, pyriform to obovate, 1,000 $1,400 \times 400-750 \mu \mathrm{m}, 3-5$ plicate, gradually narrowed to beaked mouth, commonly with 'keels' and area near the beak purple-red colored; perigynium absent; bracts similar to large leaves, loosely sheathing the perianth in the base and deflexed to obliquely spreading above. Capsule nearly spherical to shortly obovate, $450-500 \times 450 \mu \mathrm{m}$, bistratose; outer layer composed by subquadrate cells $27-45 \times 20-38 \mu \mathrm{m}$, with $2-3$ nodulose thickenings in each vertical wall and 1-2 thickenings in horizontal ones; inner cells oblong, flexuous, 38-50 × 10 $15 \mu \mathrm{m}$, with 3-6 semicircular bands. Elaters bispiral, 120-150 $\times 6-7 \mu \mathrm{m}$, with homogenous ends $12-25 \mu \mathrm{m}$ long. Spores brown, finely papillose.

Ecology: Acidophilic mesophyte, occupying partially shaded cliffs and their crevices in the broadleaved forest belt from 800 to $1,700 \mathrm{~m}$ a.s.l.

Distribution: This species was collected several times across the southern slope of the Jirisan Mt. but was not found 
Table 1. Distinctions of Solenostoma jirisanense from morphologically related taxa

\begin{tabular}{|c|c|c|c|c|}
\hline Feature & S. jirisanense & S. sunii & S. pseudopy-riflorum & S. pyriflorum \\
\hline Inflorescence & Dioicous (?) & Dioicous & Paroicous & Paroicous \\
\hline Growth form & Prostrate & Prostrate & Ascending to erect & Ascending to erect \\
\hline Rhizoid color & $\begin{array}{c}\text { Colorless to purplish, rarely } \\
\text { purple in some parts of the stem }\end{array}$ & Purple & Colorless to pink & Colorless \\
\hline $\begin{array}{l}\text { Presence of red pigmentation in } \\
\text { upper part of leaves }\end{array}$ & + & - & + & - \\
\hline Perianth shape and position & $\begin{array}{c}\text { Obovate, at almost right angle } \\
\text { with stem axis }\end{array}$ & $\begin{array}{l}\text { Fusiform to obovat } \\
\text { same axis with }\end{array}$ & $\begin{array}{l}\text { Obovate, at the same axis } \\
\text { with stem }\end{array}$ & $\begin{array}{l}\text { Obovate, at the same } \\
\text { axis with stem }\end{array}$ \\
\hline
\end{tabular}

anywhere else in the Korean Peninsula or in adjacent lands. Therefore, due to the data in hand, this is a local endemic taxon.

Other specimens examined (paratypes): Gyeongsangnamdo: Jirisan Mt., elev. 1,300-1,400 m, Bakalin Kor-22-5-15; elev. 1,500-1,600 m, Bakalin Kor-23-10-15, Kor-23-1-15; elev. 1,700-1,800 m, Bakalin Kor-25-5-15 (VBGI).

Comments: Solenostoma jirisanense is characterized by (1) prostrate growth form (including also perianthous shoots) with the perianth suddenly turned up in the female branches, (2) regularly present red to purple pigmentation of shoots that may be localized in the upper halves of leaves or limited to parts of leaves adjacent to the stem or distributed evenly, (3) variation of rhizoid color from colorless to purple, (4) frequent presence of biconcentric oil-bodies. This species is somewhat related to S. pyriflorum, $S$. sunii and $S$. pseudopyriflorum, the main differences are outlined in Table 1.

As is evident from Table 1, the new species is most closely related to $S$. sunii, although differing in ecology, coloration, as well as perianth shape and position. The two taxa also differ genetically, which might be unexpected because of the confusion in primary identification. Bakalin and Vilnet (2009) sequenced material identical with the type specimen of $S$. jirisanense (Kor-8-5-09 was collected at the same time as the type in the course of a joint expedition, from the same cliff and represents a part of type), but identified it as S. pyriflorum 'mod. prostrata'. At that time, they needed to show the distance of $S$. pseudopyrifloum from taxa closely related morphologically. Later, using the same sequence data, they showed it distant from a misinterpreted S. major (S. Hatt.) Bakalin \& Vilnet (Bakalin and Vilnet 2012) correctly named later as S. sunii Bakalin \& Vilnet (Bakalin et al., 2014). Shortly after Shaw et al. (2015) included the aforementioned data from the GenBank into their phylogenetic tree along with newly obtained sequence of 'S. pyriflorum' from North America (most probably belonging to the recently validated $S$. appalachianum R. M. Schust. ex Bakalin (cf. Bakalin, 2014b)).
The phylogenetic tree in Shaw et al. (2015) also showed the strong distance of $S$. jirisanense from $S$. appalachianum. It is odd that despite so many sequences, there is no available data on the genetic structure of 'true' S. pyriflorum from Japan.

\section{Key to the S. jirisanense and related Korean taxa}

1. Rhizoids mostly colorless, rarely purplish; plants commonly with rusty to reddish pigmentation; perianth suddenly turned upward (at almost right angle with stem axis); $\quad 10-50 \%$ of oil-bodies with central eye (biconcentric); plants occupying mesic habitats ...............

S. jirisanense

1. Rhizoids mostly purple, rarely with small admixture of colorless; plants without rusty or reddish pigmentation (but commonly brown to brownish); oil-bodies never biconcentric; plants occupying wet habitats (also growing submerged) S. sunii

5. Solenostoma minutissimum (Amakawa) Bakalin, Vilnet \& Furuki, Bot. Pacif. 3: 15, 2014 (Figs. 15L-Q, 16A, B). Jungermannia pyriflora var. minutissima Amakawa, Journ. Hattori Bot. Lab. 22: 61, 1960.

Korean name: Tam-ra-mang-ul-i-kki (탐라망울이끼).

Ecology: Acidophilic to neutro-tolerant mesophyte, occupying partially shaded to open cliff crevices filled with soil and soil-covered rocks. It occurs in broadleaf-deciduous to deciduous-evergreen forest belts. The species is rare in the Korean flora and only a few specimens are known. It mostly forms pure patches or is associated with Lophocolea horikowana and Marsupella tubulosa.

Distribution: The distribution of the species is poorly understood because of confusion with Solenostoma pyriflorum. Based on data in hand this species is disjunctively distributed 
broadly across East Asian (although we doubt its 'disjunctivity'), known from several localities in middle to southern Japan, one locality from Korean Jeju-do Island and isolated findings in Chinese Yunnan and Indian Madras (Bakalin et al., 2014).

Comments: This species is distinctive due to its relatively small size and shoots evidently dilated to the perianth. The only species with which it is easily mistaken in our regional flora is Solenostoma pyriflorum. However, S. minutissimum differs from the latter in its ability to develop purple rhizoids, and shoots dilated to the perianth (versus not dilated) and mostly prostrate growth form. The species status for this taxon was also verified by genetic data (Bakalin et al., 2014).

6. Solenostoma obscurum (A. Evans) R. M. Schust., Rhodora 59: 252, 1957 (Fig. 16C-J). Nardia obscura A. Evans, Rhodora 21: 159, 1919.

Korean name: Gu-seul-mang-ul-i-kki (구슬망울이끼).

Ecology: Acidophilic meso- to hygrophyte, occupying partially shaded to open places in high elevations of mountains (crooked Betula-Picea forests).

Distribution: Amphi-North Pacific - western AmphiAtlantic, with the locality in Korea being the southernmost in
Asia. In Korea it is only known from Seorak Mt. (Gangwondo) and is an evident northern element in the Korean flora (reflecting its northern relation).

Comments: This is a more or less easily recognized species having no close relatives in Korea. It may be mistaken with Plectocolea ovalifolia, from which differs in a tall perigynium (two or more times higher than perianth) and differentiation of stem cross section into three more or less distinct strata.

7. Solenostoma purpuratum (Mitt.) Steph. var. koponenii Bakalin \& Li Wei, Arctoa 22: 135, 2013 (Fig. 17).

Korean name: Baek-mu-mang-ul-i-kki (백무망울이끼).

Ecology: Acidophilic hygro- to hydrophyte, growing on wet fine soil along streams, in partial shade, in broadleaved evergreen-deciduous forests at middle elevations of mountains in southernmost flank of Korea proper. Based on very limited information from the treated area, this species forms pure mats or grows together with Marsupella apertifolia.

Distribution: Poorly understood, known from three localities only: Chinese Sichuan, Sikkim and southern flank of Korea. Probably the distribution of the taxon is somewhat similar to Solenostoma pseudocyclops (Inoue) Váňa \& D. G. Long that is generally Himalayan, but also occurs in Taiwan.

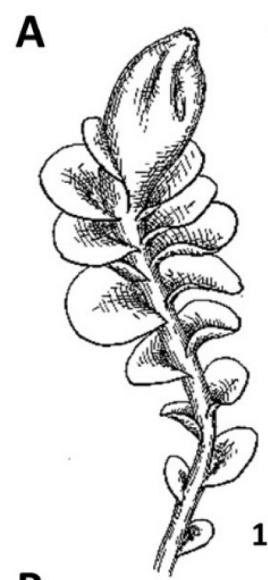

B

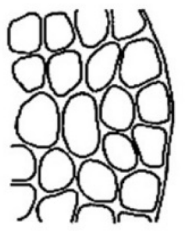

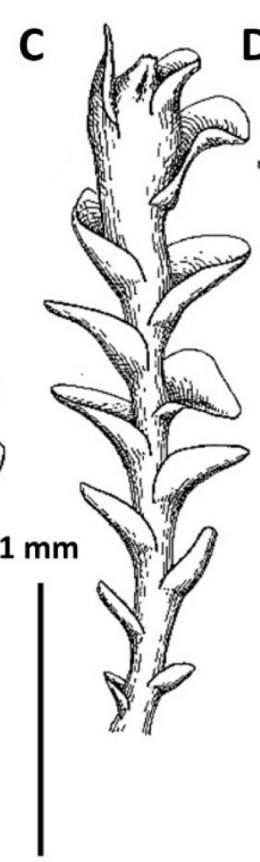
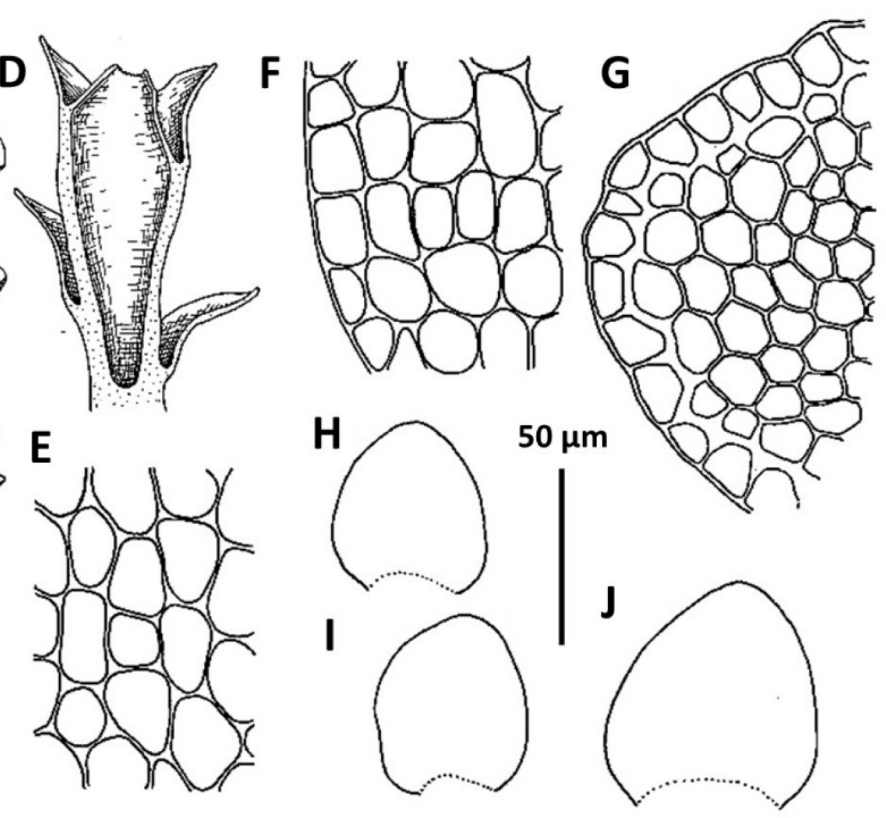

Fig. 16. Solenostoma minutissimum (Amakawa) Bakalin, Vilnet \& Furuki. A, B. A. Perianthous plant. B. Cells along leaf margin (from Choi 111307). Solenostoma obscurum (A. Evans) R. M. Schust. C-J. C. Perianthous branch. D. Perianth longitudinal section. E. Midleaf cells. F. Cells along leaf margin. G. Stem cross section fragment. H-J. Leaves (from Choi 110353). Scale bars = $1 \mathrm{~mm}$ (A, C, D, H-J), $50 \mu \mathrm{m}$ (B, E-G). 


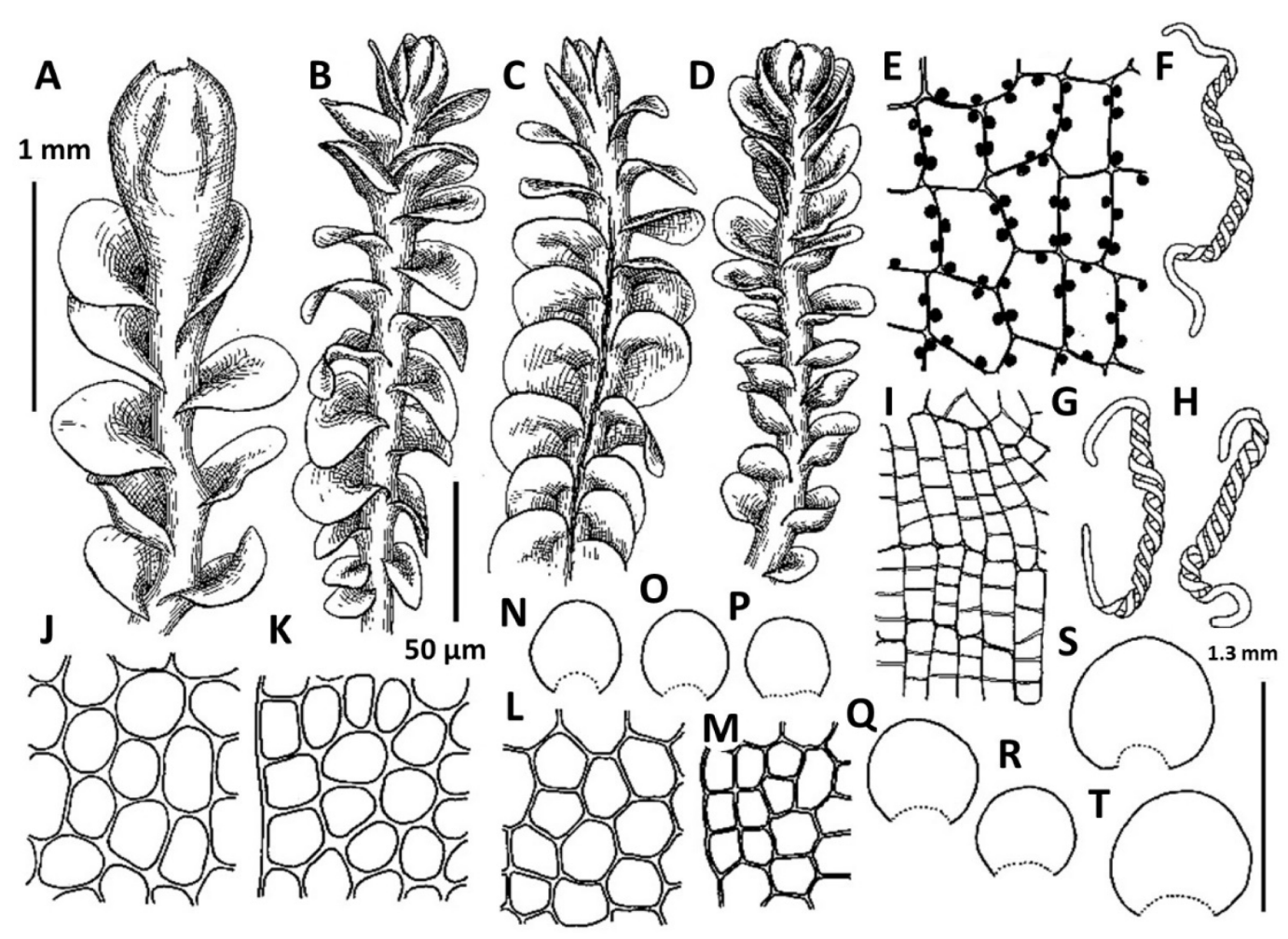

Fig. 17. Solenostoma purpuratum (Mitt.) Steph. var. koponenii Bakalin et Li Wei. A. Perianthous branch. B. Sterile branch. C. Sterile branch, ventral view. D. Male branch. E. Capsule wall, outer layer cells. F-H. Elaters. I. Capsule wall, inner layer cells. J, L. Midleaf cells. K, M. Cells along leaf margin. N-R. Leaves. S-T. Bracts (from Choi 120375). Scale bars =1 mm (A-D), $1.3 \mathrm{~mm}(\mathrm{~N}-\mathrm{T}), 50 \mu \mathrm{m}(\mathrm{E}-\mathrm{M})$.

Although a Korean-Himalayan relationship in hepatics has not been suggested previously, the present record may confirm the existence of such a relationship.

Comments: The variety was described from Chinese Sichuan (Bakalin and $\mathrm{Li}, 2013$ ) and then was found to be identical with Solenostoma gollanii Steph. (Sp. Hepat. 6: 81, 1917) described from Sikkim (with the name S. purpuratum var. koponenii having priority if the taxon is treated at the varietal rank). Whether the taxon requires species status is a question for further studies.

The species has a very distinctive appearance due to an absence of red or rusty pigmentation in the shoots and particularly due to rhizoids decurrent down along the stem in distinct fascicles. The only possible relative we could see is Solenostoma appressifolium (Mitt.) Vaňa \& D. G.Long (not known in Korea proper, but possibly could be found there), from which S. purpuratum var. koponenii differs in smaller size (narrower than $1.3 \mathrm{~mm}$ versus wider than $1.5 \mathrm{~mm}$ ), obliquely spreading canaliculate leaves (versus leaves laterally appressed to the stem and slightly concave to almost plane) and much wider leaves (less than $0.9 \mathrm{~mm}$ wide in $S$. purpuratum var. koponenii versus wider than $1.4 \mathrm{~mm}$ in $S$. appressifolium). The distinctions of the taxon from S. cyclops, confusion with which seems improbable, are discussed under the latter.

8. Solenostoma pyriflorum Steph., Sp. Hepat. 6: 83, 1917. (Fig. 18A-I). Plectocolea pyriflora (Steph.) S. Hatt., Bull. Tokyo Sci. Mus. 11: 38, 1944.

Jungermannia pyriflora Steph., Sp. Hepat. 6: 90, 1917.

Korean name: Dung-geun-mang-ul-i-kki (둥근망울이끼).

Ecology: Acidophilic mesophyte, occupying partially shaded to nearly open fine mineral soil along water courses or growing on soil-covered rocks in the broadleaved forest belt.

Distribution: Temperate Montane East Asian species, common in Japan and sparsely (to disjunctively?) distributed in the Korean Peninsula and China (where recorded from Xizang, Jilin and Taiwan, but some records may be based on misidentification of $S$. minutissimum). Solenostoma pyriflorum was frequently recorded for the Russian Far East and South Siberia, but all these records were based on misidentifications (cf. Bakalin and Vilnet, 2009). In Korea this species has been recorded for Jeju-do, Gyeongsangbuk-do, Chungcheongnam- 


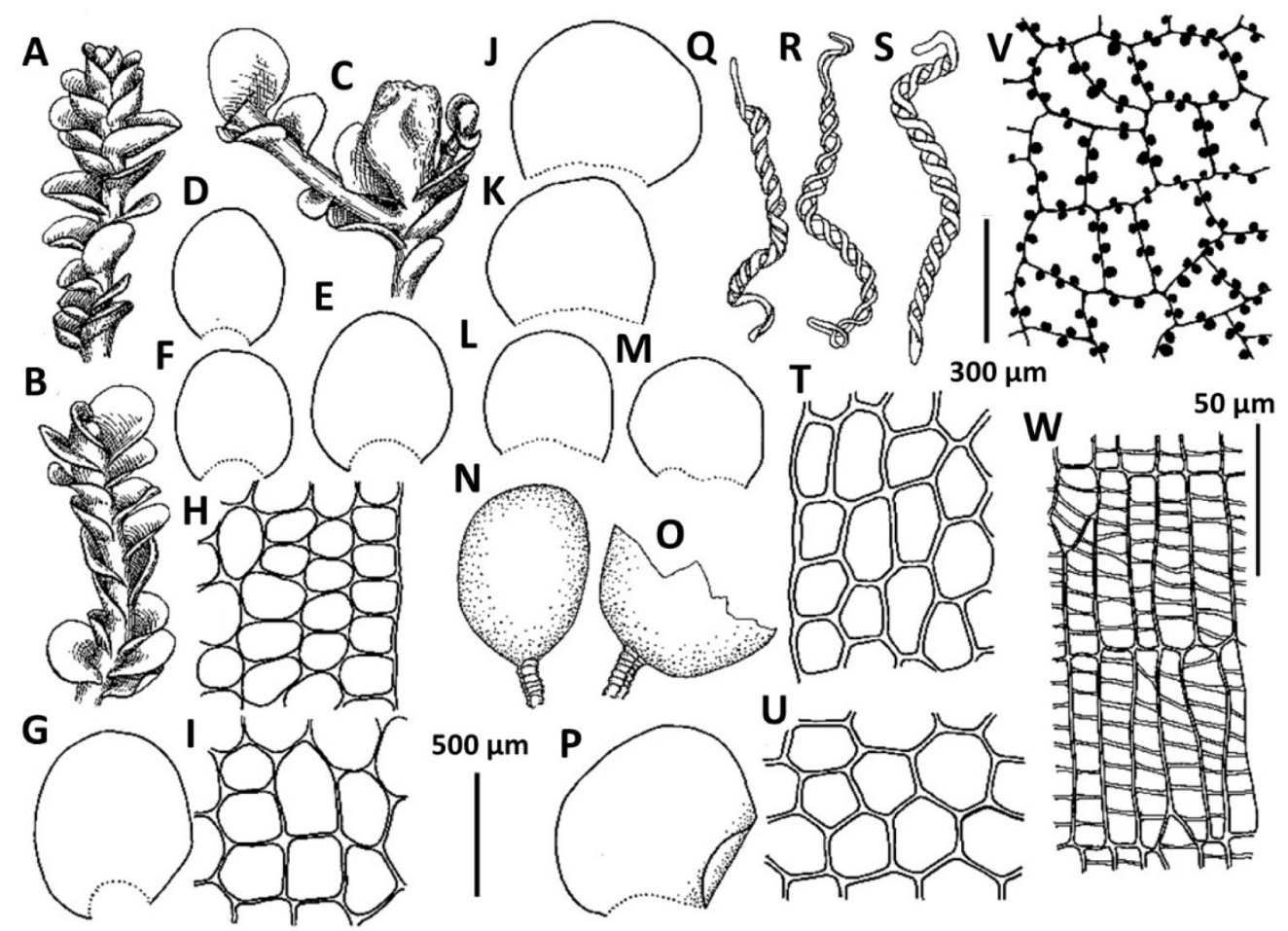

Fig. 18. Solenostoma pyriflorum Steph. A-I. A. Male branch. B. Sterile branch. C. Female branch fragment. D-G. Leaves. H. Cells along leaf margin. I. Midleaf cells (from Choi 8724). Solenostoma rotundatum Amakawa. J-W. J-M. Leaves. N, O. Antheridia. P. Female bracts. Q-S. Elaters. T. Cells along leaf margin. U. Midleaf cells. V. Capsule wall outer layer cells. W. Capsule wall inner layer cells (from Choi 111381 ). Scale bars $=500 \mu \mathrm{m}(\mathrm{A}-\mathrm{C}, \mathrm{J}-\mathrm{M}, \mathrm{P}), 300 \mu \mathrm{m}(\mathrm{D}-\mathrm{G}), 50 \mu \mathrm{m}(\mathrm{H}, \mathrm{I}, \mathrm{N}, \mathrm{O}, \mathrm{Q}-\mathrm{W})$.

do, Gyeongsangnam-do, Yanggang-do (Kim and Hwang, 1991; Yamada and Choe, 1997), but we suggest that some of these records are based on misidentifications. The species, we assume, is not as common in Korea proper as might be suggested from literature sources and its main area core lies in Japan. We were able to confirm it from Gyeongsangbuk-do and Gyeongsangnam-do.

Comments: The species is characterized by subtransversely inserted leaves, erect or nearly so growth type, totally colorless to brownish rhizoids (no purple pigmentation). All known populations from the Korean Peninsula represent a smaller modification in general size than those from typical localities from Japan (cf. description in Bakalin, 2014b). However, in other essential features, including growth form, coloration, leaf cell size and other characters, perianth shape and folding, it fully corresponds to the type.

9. Solenostoma rotundatum Amakawa, J. Jap. Bot., 31: 50, 1956 (Figs. 18J-W, 19A-C). Jungermannia rotundata (Amakawa) Amakawa, J. Hattori Bot. Lab., 22: 73, 1960.

Plectocolea harana Amakawa, Misc. Bryol. Lichenol., 2: 33, 1960.
Korean name: San-mang-ul-i-kki (산망울이끼).

Ecology: Acidophilic hygrophyte, occupying partially shaded fine soil and mineral soil covering rocks along streams in broadleaved deciduous to evergreen forests.

Distribution: Temperate East Asian species largely spreading southward to subtropics of southernmost Ryukyu. It seems to be common in the southern half of Japan and more or less sparsely distributed in its northern half, also known from Chinese Liaoning and Russian South Kurils. In Korea proper it seems to be more or less common in the southern half of South Korea but becomes much sparser northward. Solenostoma rotundatum was recorded in Korea proper for Jeju-do, Jeollabuk-do, Gyeongsangnam-do, Gyeongsangbukdo (Yamada and Choe, 1997). We found it also in Gangwondo and Jeollanam-do.

Comments: This species is difficult to mistake with other members of the Solenostomataceae known in Korea. Its basic characteristics include deep purple rhizoids decurrent down the stem in fertile plants but not forming distinct fascicles, erect growth of female plants and creeping sterile plants, limited number of oil-bodies with (1)2(3) per cell, and loosely emarginate larger leaves near the perianth. 

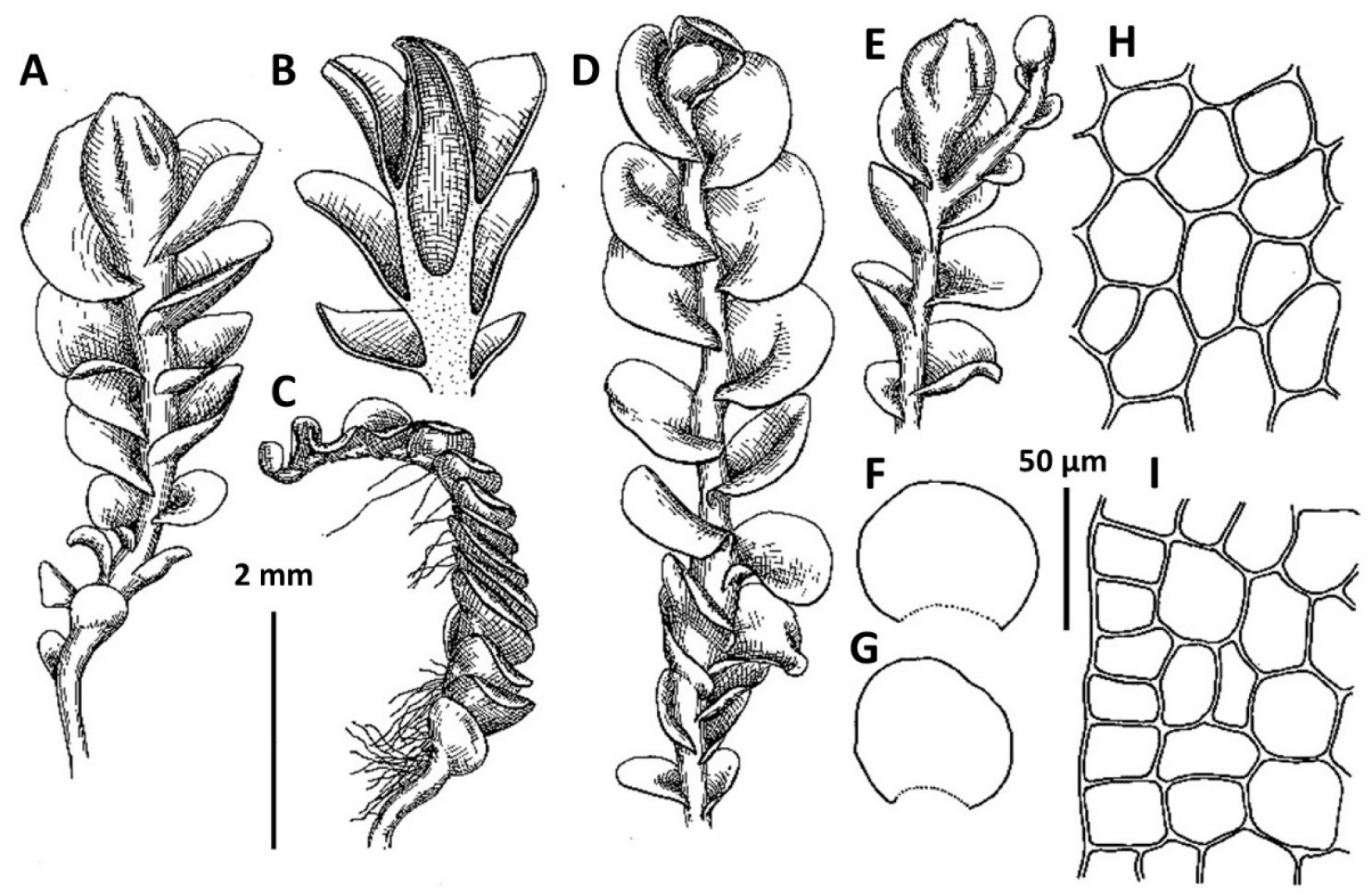

Fig. 19. Solenostoma rotundatum Amakawa. A-C. A. Perianthous branch. B. Perianth longitudinal section. C. Male branch (from Choi 111381). Solenostoma sunii Bakalin \& Vilnet. D-I. D. Sterile branch. E. Perianthous branch. F, G. Leaves. H. Midleaf cells. I. Cells along leaf margin (from Choi 3759). Scale bars $=2 \mathrm{~mm}(\mathrm{~A}-\mathrm{G}), 50 \mu \mathrm{m}(\mathrm{H}, \mathrm{I})$.

10. Solenostoma sunii Bakalin \& Vilnet, Bot. Pacif. 3: 15, 2014 (Figs. 19D-I, 20X).

Jungermannia monticola S. Hatt. f. major S. Hatt., J. Hattori Bot. Lab. 3: 8, 1950. auct. non; Solenostoma major (S. Hatt.) Bakalin \& Vilnet, Bryologist 115: 574, 2012. auct. non.

Korean name: Sun-mang-ul-i-kki (선망울이끼).

Ecology: Acidophilic hygro- to hydrophyte, growing over partially shaded stones on cliffs wetted with percolate water or along streams, sometimes even growing submerged in rheophilous communities. Solenostoma sunii occurs in hemiboreal mixed to cool temperate broadleaved (very rarely warm temperate evergreen) forest belts in middle to higher elevations of mountains (with the type from subalpine PiceaAbies forest in Jiri Mt.).

Distribution: Temperate East Asian, recently recognized taxon, known from a limited number of localities in the southern parts of the Japan Archipelago (excluding Ryukyu) and Korea proper (Gyeongsangnam-do, Jeju-do, Jeollabuk-do).

Comments: This is the most hydrophytic species of Solenostoma in the Korean Peninsula resistant to constant flushing by running water. In terms of habitat, in Japan the species is not so hydrophytic, but rather hygro-mesophytic, and, consequently, whether or not Japanese and Korean populations are identical is questionable. The habitat, transversely elliptic and sometimes truncate leaves, as well as purple and rigid rhizoids are diagnostic. Some relationships can be observed between the present species and Solenostma jirisanense and these are discussed under the latter.

\section{Doubtful or unconfirmed records}

1. Plectocolea flagellata S. Hatt., J. Hattori Bot. Lab. 3: 13. f. 13: n-o, 18, 1948 [1950]. Jungermannia flagellata (S. Hatt.) Amakawa, J. Hattori Bot. Lab. 22: 16, 1960.

The species has a distinct south Japanese distribution and is very peculiar in appearance due to rigid, large (3--4 mm wide) plants, canaliculate and enclosed one to another leaves, erect growth, purple rhizoids not forming distinct fascicles, common ventral leafless geotropic stolons and botryoidal oil-bodies. The species was recorded for Gyeongsangnam-do (Yamada and Choe, 1997) but that seems to be doubtful if general distribution patterns of the species are taken into account. The appropriate figures and description of the species were published by Amakawa (1960).

2. Plectocolea hyalina (Lyell) Mitt., Trans. Linn. Soc. London, Bot. 3: 198, 1891. Jungermannia hyalina Lyell, Brit. 


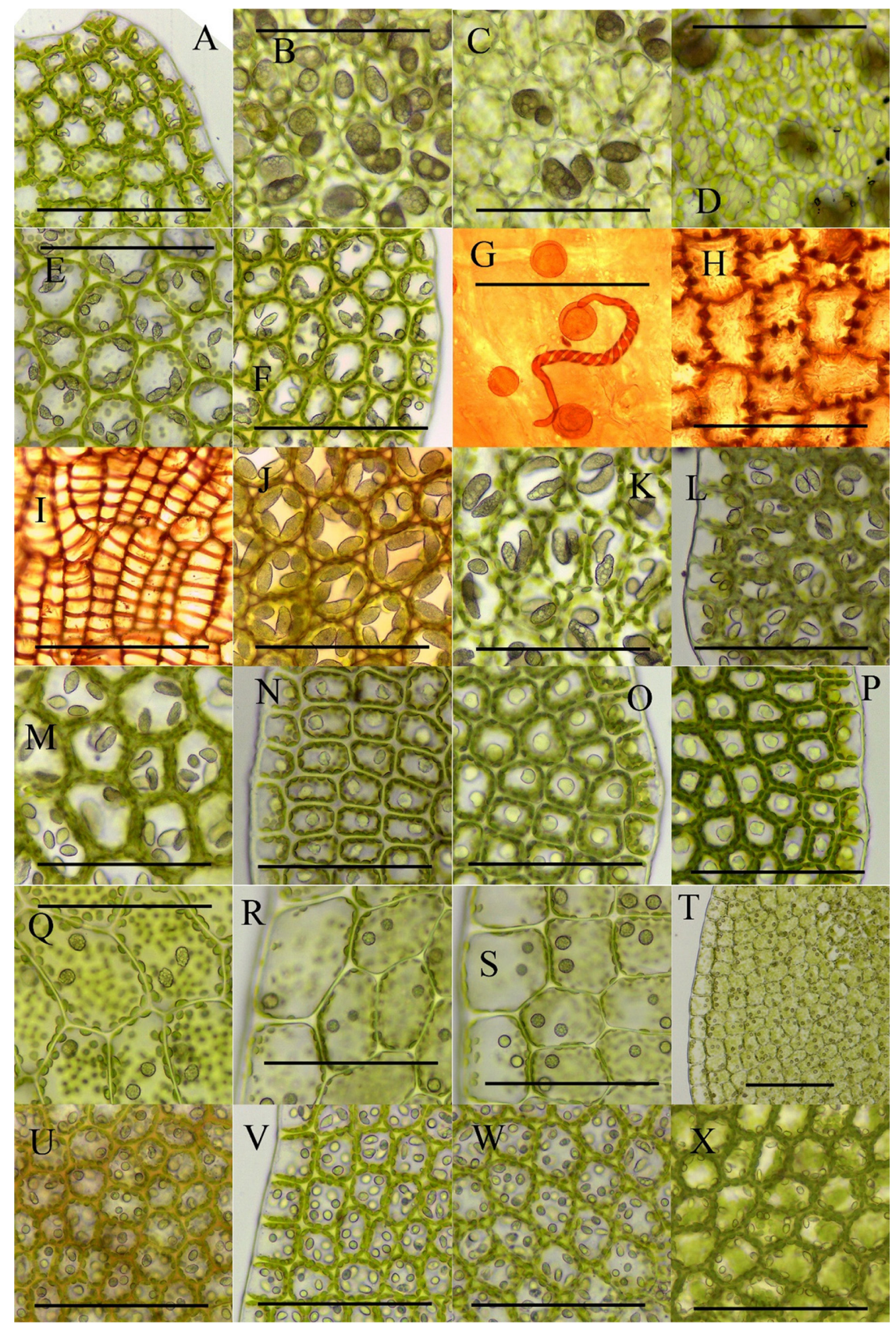

Fig. 20. Oil bodies of Solenostomataceae in Korean peninsula. A. Solenostoma bilobum (Amakawa) Potemkin \& Nyushko, oil bodies in upper half of the leaf (from Bakalin kor-29-27-15). B-D. Plectocolea comata S. Hatt. B. oil bodies in the midleaf cells (from Bakalin kor-30-57-15). C. Oil bodies in the cells near leaf base (from Bakalin kor-30-57-15). D. Papillose leaf cuticle in the midleaf (from Bakalin kor-30-57-15). E-I. Plectocolea erecta Amakawa. E. Oil bodies in the midleaf (from Bakalin kor-23-6-15). F. Oil bodies in the cells along leaf margin (from Bakalin kor-23-6-15). G. Spores and elater (from Choi 110379). H. Capsule outer wall cells (from Choi 110379). I. Capsule inner wall cells (from Choi 110379). J. Plectocolea infusca var. recondita Bakalin, oil bodies in the midleaf (from Bakalin kor-15-13-15). K, L. Plectocolea radicellosa (Mitt.) Mitt. K. Oil bodies in the midleaf cells (from Bakalin kor-30-64-15). L. Oil bodies in the cells along leaf margin (from Bakalin kor-30-53-15). M. Plectocolea rosulans (Steph.) S. Hatt., oil bodies in the midleaf cells (from Bakalin kor-29-38-15). N-P. Plectocolea virgata Mitt. N. Oil bodies in the cells along leaf margin (from Bakalin kor-29-5-15). O. Oil bodies in the cells along leaf margin (from Bakalin kor-30-47-15). P. Oil bodies in the cells along leaf margin (from Bakalin kor-29-21-15). Q-T. Protosolenostoma fusiforme (Steph.) Vilnet \& Bakalin. Q. Oil bodies in the midleaf cells (from Bakalin kor-29-46-15). R. Oil bodies in the cells along leaf margin (from Bakalin kor-29-46-15). S. Oil bodies in the cells along leaf margin (from Bakalin kor-29-46-15). T. Oil bodies in the cells along leaf margin (from Bakalin kor-29-46-15). U-W. Solenostoma jirisanense Bakalin \& S. S. Choi. U. Oil bodies in the midleaf cells (from Bakalin kor-23-10-15). V. Oil bodies in the cells along leaf margin (from Bakalin kor-23-1-15). W. Oil bodies in the midleaf cells (from Bakalin kor-23-115). X. Solenostoma sunii Bakalin \& Vilnet, oil bodies in the midleaf cells (from Bakalin kor-25-14-15). Scale bars $=100 \mu \mathrm{m}(\mathrm{A}-\mathrm{S}, \mathrm{U}-\mathrm{X}), 200 \mu \mathrm{m}(\mathrm{T})$. 
Jungermann. Pl. 63, 1814.

The species is characterized by a boreo-temperate montane circumpolar distribution. In adjacent areas, it is known from the Russian Far East (being rare in its southern half), the northern half of Japan, North-East China (Jilin, Liaoning) and also known in China from Jiangsu, Sichuan, Taiwan and Yunnan (in the latter four provinces associated with high elevations in mountains). In Korea it has been recorded for Chungcheongbuk-do, Gangwon-do, Gyeonggi-do (Yamada and Choe, 1997) and also for Jeonnam Province (Bakalin 2014a), but the latter record (probably as well as those cited by Yamada and Choe, 1997) is a misidentification for Metasolenostoma ochotense, with which Plectocolea hyalina may be confused and that is discussed under the former. Additional confusion seems to be possible with Plectocolea infusca, from which $P$. hyalina differs in widely lingulate (versus ovate) leaves with commonly truncate to emarginate (versus rounded) apices of larger leaves, dull color of plants (versus more or less bright) and particularly in grayish oil bodies not filling cell lumina (versus brownish and filling cell lumina; oil-bodies of 'infusca-type').

3. Plectocolea otiana S. Hatt., J. Jap. Bot. 28: 183. f. 65, 1953. Jungermannia otiana (S. Hatt.) Amakawa, J. Hattori Bot. Lab. 22: 27, 1960.

The species is a Japanese temperate lowland endemic, also recorded for Gyeongsangnam-do in Korea (Yamada and Choe, 1997) and may be easily recognized due to its monoicous inflorescence. The nearest monoicous morphological ally is Solenostoma subellipticum (Lindb. ex Heeg) R. M. Schust. with its known southernmost locations in East Asia from middle Sakhalin Island and the lower course of the Amur River (Bakalin 2014). Plectocolea otiana easily differs from the latter in large $(40-70 \times 30-40 \mu \mathrm{m})$ midleaf cells and a shorter perigynium (less than perianth length). The distribution of $P$. otiana in the Korean Peninsula seems to be likely possible and appropriate figures and description of the latter may be found in Amakawa (1960).

4. Plectocolea horikowana Amakawa, J. Jap. Bot. 32: 219. f. $8,1957$.

The name mentioned in the dataset originated by Bakalin and Vilnet (2012) is based on misidentification of weakly developed, prostrate modification of $P$. virgata (see also above the discussion on $P$. virgata).

ORCID: Vadim BAKALIN https://orcid.org/0000-0001-78974305; Seung Se CHOI https://orcid.org/0000-0002-3332-5544;
Seung Jin PARK https://orcid.org/0000-0002-7967-8361; Sun Hee SIM https://orcid.org/0000-0001-9788-7653; Chang Woo HYUN http://orcid.org/0000-0001-9677-5270

\section{Acknowledgments}

We are deeply indebted to Dr. W.R. Buck for language correction in the manuscript. The work was supported by the grant "Biological Diversity Survey of the Flora of Korean Bryophyta (NIBR201902104)" from the National Institute of Biological Resources of Ministry of Environment in Korea to C.W. Hyun. The line art drawings were provided by Mr. M. Bakalin to whom authors are sincerely grateful the work of Bakalin was partially supported by grants from the Russian Foundation for Basic researches (17-04-00018 and 20-0400278).

\section{Conflict of Interest}

The authors declare that there are no conflicts of interest.

\section{Literature Cited}

Ahn, Y. S. 2011. National List of Species of Korea (Mosses, Liverworts). National Institute of Biological Resources, Incheon, 161 pp. (in Korean)

Amakawa, T. 1960. Family Jungermanniaceae of Japan. II. Journal of Hattori Botanical Laboratory 22: 1-90.

Bakalin, V. A. 2014a. The Revision of 'Jungermannia s.l.' in the North Pacific: the Genera Endogemma, Jungermannia s. str., Metasolenostoma, Plectocolea and Solenostoma (Hepaticae). Botanica Pacifica 3: 55-128.

Bakalin, V. A. 2014b. The study of type collection in Conservatoire et Jardin Botanique de la Ville de Genève $(\mathrm{G})$ : the hepatic genera Jungermannia, Solenostoma and Plectocolea. Arctoa 23: 91-136.

Bakalin, V. A. 2016. The identity of Plectocolea unispiris Amakawa (Solenostomataceae). Arctoa 25: 301-305.

Baklain, V.A. and S.S. Choi. 2017. Solenostomataceae. In Liverworts and Hornworts Flora of Korea, Vol. 2. ScapaniaceaeDendrocerotaceae. Choi, S. S., V. A. Bakalin, S. J. Park and E. H. Ra. (eds.), National Institute of Biological Resources, Ministry of Environment, Incheon. Pp. 64-84.

Bakalin, V. A. and W. Li. 2013. Two new taxa of Solenostoma (Solenostomataceae, Hepaticae) from China. Arctoa 22: 135138.

Bakalin, V. A. and A. A. Vilnet. 2009. Two new species of Jungermanniaceae from Asiatic Russia. Arctoa 18: 151-162. 
Bakalin, V. A. and A. A. Vilnet 2012. New combinations and new species of Solenostoma and Plectocolea (Solenostomataceae) from the Russian Far East. The Bryologist 115: 566-584.

Bakalin, V. A., A. A. Vilnet, T. Furuki and T. Katagiri. 2014. Taxonomic novelties in Solenostoma: Plectocolea complex (Solenostomataceae, Hepaticae) in East Asia. Botanica Pacifica 3: 3-18.

Crandall-Stotler, B., R. E. Stotler and D. G. Long. 2009. Phylogeny and classification of the Marchantiophyta. Edinburgh Journal of Botany 66: 155-198.

Feldberg, K., J. Hentschel, A. Bombosch, D. G. Long, J. Váña and J. Heinrichs. 2009. Transfer of Gottschelia grollei, G. patoniae and Scaphophyllum speciosum to Solenostoma based on chloroplast DNA $r b c \mathrm{~L}$ sequences. Plant Systematics and Evolution 280: 243-250.

Hong, W. S. 1962. Studies on the Hepaticae of Korea. Theses of Catholic Medical College 5: 425-589.

Kim, Y. H. and H. J. Hwang. 1991. Korean Spore Plant 8 (Hepaticae). Publiching House of Science on Encyclopodia, Pyongyang, 223 pp. (in Korean)

Konstantinova, N. A., V. A. Bakalin, E. N. Andrejeva, A. G. Bezgodov, E. A. Borovichev, M. V. Dulin and Y. S. Mamontov. 2009. Checklist of liverworts (Marchantiophyta) of Russia.
Arctoa 18: 1-64.

Piippo, S. 1990. Annotated catalogue of Chinese Hepaticae and Anthocerotae. Journal of the Hattori Botanical Laboratory 68: $1-192$.

Shaw, B., B. Crandall-Stotler, J. Váňa, R. E. Stotler, M. von Konrat, J. J. Engel, E. C. Davis, D. G. Long, P. Sova and A. J. Shaw. 2015. Phylogenetic relationships and morphological evolution in a major clade of leafy liverworts (phylum Marchantiophyta, order Jungermanniales): suborder Jungermanniineae. Systematic Botany 40: 27-45.

Váňa, J. and H. Inoue. 1983. Studies on Taiwan Hepaticae V. Jungermanniaceae. Bulletin of the National Science Museum Series B (Botany) 9: 125-142.

Vilnet, A. A., N. A. Konstantinova and A. V. Troitsky. 2011. Taxonomical rearrangements of Solenostomataceae (Marchantiophyta) with description of a new family Endogemmataceae based on trnL-F cpDNA analysis. Folia Cryptogamica Estonica 48: $125-133$.

Yamada, K. and D.-M. Choe. 1997. A checklist of Hepaticae and Anthocerotae in the Korean peninsula. Journal of the Hattori Botanical Laboratory 81: 175-242.

Yamada, K. and Z. Iwatsuki. 2006. Catalog of the hepatics of Japan. Journal of the Hattori Botanical Laboratory 99: 1-106.

\section{Appendix. 1. Examined specimens of Solenostomataceae species in Korean Peninsula}

Here and below in specimens examined we cite only one specimen per each locality with the purpose to economize the space. Also, we do not repeat the specimens already cited from the Korean Peninsula by Bakalin (2014b). Only specimens from the Korean Peninsula are cited

\section{Metasolenostoma ochotense Vilnet et Bakalin 오름망울이끼}

Specimens examined: REPUBLIC OF KOREA. Jeju-do: Hannam Experimental forest, $476 \mathrm{~m}$, Choi 111730 (JNU); Sumeunmulbyengdwi, elev. 992 m, Choi 8041 (JNU). Jeollabuk-do: Deogyusan Mt., Choi 633 (JNU). Jeollanam-do: Heuksando Isl., Choi site2-3 (JNU).

Plectocolea comata S. Hatt. 비짜루망울이끼

Specimens examined: REPUBLIC OF KOREA. Jeju-do: Donnaeko stream, elev. 172 m, Choi 111391 (JNU), elev. 200-350 m alt., Bakalin Kor-30-57-15 (VBGI), Soesokkak stream, elev. 73 m, Choi 120873 (JNU).

Plectocolea erecta Amakawa 곧은망울이끼

Specimens examined: REPUBLIC OF KOREA. Chungcheongnam-do: Daedunsan Mt., elev. 343 m, Choi 3366 (JNU); Gyeryongsan Mt., elev. 357 m, Choi 4104 (JNU). Gangwon-do: Seoraksan Mt., elev. 937 m, Choi 8628 (JNU); elev. 805 m, Choi 8645 (JNU). Gyeongsangbuk-do: Ulleungdo Isl., Bongrae waterfall, Choi site4-224 (JNU). Gyeongsangnam-do: Gayasan Mt., elev. 1,350 m, Choi 7424a (JNU); Jirisan Mt., elev. 904 m, Choi 8178 (JNU); elev. 1,500-1,600 m alt. Bakalin Kor-23-6-15 (VBGI); Namdeogyusan Mt., Choi 276 (JNU). Jeju-do: Hallasan Mt., elev. 1,687 m, Choi 110379, 110403 (JNU). Jeollabuk-do: Deogyusan Mt., Choi 614 (JNU), Jirisan Mt., elev. 1,300 m, Choi 6066 (JNU).

Plectocolea granulata (Steph.) Bakalin 열대망울이끼

Specimens examined: REPUBLIC OF KOREA. Jeju-do: Sumeunmulbyengdwi, elev. 992 m, Choi 8019 (JNU). 
Plectocolea grossitexta (Steph.) S. Hatt. 바다망울이끼

Specimens examined: REPUBLIC OF KOREA. Jeju-do: Sumeunmulbyengdwi, elev. 992 m, Choi 8057 (JNU).

Plectocolea infusca Mitt. var. infusca 큰망울이끼

Specimens examined: REPUBLIC OF KOREA. Gyeongsangbuk-do: Sinbulsan Mt., elev. 987 m, Choi 8328 (JNU), Ulleungdo Isl., Seonginbong, elev. 977 m, Choi 8745 (JNU). Gyeongsangnam-do: Hwangmaesan Mt., elev. 908 m, Choi 7500 (JNU); Jirisan Mt., elev. 848 m, Choi 3626 (JNU); elev. 1,300 m, Choi 3855 (JNU). Jeju-do: Bolrae Oreum, elev. 1,230 m, Choi 111429 (JNU); Che Oruem, elev. 271 m, Choi 8061 (JNU); Hannam Experimental forest, elev. 476 m, Choi 111734 (JNU); Hyodon stream, elev. 461 m, Choi 7602 (JNU); Musu stream, elev. 495 m, Choi 8823 (JNU). Jeollabuk-do: Deogyusan Mt., Choi 596 (JNU); Jirisan Mt., elev. 1,300 m, Choi 6094 (JNU). Jeollanam-do: Dureunsan Mt., elev. 262 m, Choi 110506 (JNU), Seongdudo Isl., elev. 7 m, Choi 110613 (JNU); Weolchulsan Mt., elev. 441 m, Choi 9039 (JNU).

Plectocolea infusca Mitt. var. recondita Bakalin 산큰망울이끼

Specimens examined: REPUBLIC OF KOREA. Gangwon-do: Seokbyeongsan Mt., elev. 956 m, Bakalin Kor-15-13-15 (VBGI). Gyeongsangnam-do: Hangmaesan Mt., elev. 1,057 m, Choi 4388 (JNU), Namdeogyu, Choi site 2--14 (JNU). Jeju-do: Bolrae Oreum, elev. 1,230 m, Choi 111419 (JNU). Jeollabuk-do: Deogyusan Mt., Choi 417 (JNU).

Plectocolea kurilensis (Bakalin) Bakalin \& Vilnet 쿠릴망울이끼

Specimens examined: REPUBLIC OF KOREA. Jeju-do: Bolrae Oreum, elev. 1,230 m, Choi 120737 (JNU); Cheonjiyeon waterfall, elev. 156 m, Choi 8867 (JNU); Dongsu Brigde, elev. 653 m, Choi 111448 (JNU); Donnaeko stream, elev. 172 m, Choi 111383 (JNU); Hyodon stream, elev. 484 m, Choi 111259 (JNU); Musu stream, elev. 495 m, Choi 8824a (JNU).

Plectocolea ovalifolia (Amakawa) Bakalin \& Vilnet 누운큰망울이끼

Specimens examined: REPUBLIC OF KOREA. Gangwon-do: Seoraksan Mt., elev. 840 m, Choi 4255 (JNU). Gyeongsangbukdo, Ulleungdo Isl., Bongrae waterfall, Choi site 4-234 (JNU). Gyeongsangnam-do: Deogyusan Mt., Choi 455 (JNU), Gayasan Mt., elev. 1,350 m, Choi 7429 (JNU)’ Jirisan Mt., elev. 1,134 m, Choi 3702a (JNU). Jeollabuk-do: Jirisan Mt., elev. 1,202 m, Choi 8281 (JNU). Jeollanam-do: Jirisan Mt., elev. 1,222 m, Choi 3522 (JNU).

Plectocolea radicellosa (Mitt.) Mitt. 큰잎망울이끼

Specimens examined: REPUBLIC OF KOREA. Chungcheongnam-do: Gyeryongsan Mt., elev. 274 m, Choi 4115 (JNU). Jejudo: Dongsu Brigde, elev. 653 m, Choi 112265 (JNU); Donnaeko stream, elev. 172 m, Choi 111373 (JNU); elev. 200-350 m, Bakalin Kor-30-53-15, Kor-30-64-15 (VBGI); Dulle route, elev. 600-800 m, Bakalin Kor-29-7-15 (VBGI); Hyodon stream, elev. 469 m, Choi 7627 (JNU); Musu stream, elev. 469 m, Choi 8824 (JNU); Suak valley, elev. 558 m, Choi 8895 (JNU); Tamla valley, elev. 898 m, Choi 120324 (JNU).

Plectocolea rosulans (Steph.) S. Hatt. 망울이끼

Specimens examined: REPUBLIC OF KOREA. Chungcheongnam-do: Gyeryongsan Mt., elev. 290 m, Choi 4107 (JNU); Jirisan Mt., elev. 848 m, Choi 3656 (JNU); elev. 1,134 m, Choi 3695 (JNU); elev. 1,500-1,600 m, Bakalin Kor-23-3-15 (VBGI). Jejudo, Dongsu Brigde, elev. 653 m, Choi 111455 (JNU); Dulle route, elev. 600-800 m, Bakalin Kor-29-38-15 (VBGI); Hallasan Mt., elev. 1,916 m, Choi 7761 (JNU); Hyodon stream, elev. 469 m, Choi 7620 (JNU); Nokkome Oreum, elev. 618 m, Choi 8821 (JNU), Suak valley, elev. 558 m, Choi 8895 (JNU). Jeollabuk-do: Deogyusan Mt., Choi 724 (JNU). Jeollanam-do: Palyeoungsan Mt., elev. 298 m, Choi 4011 (JNU).

Plectocolea torticalyx (Steph.) S. Hatt. 보라망울이끼

Specimens examined: REPUBLIC OF KOREA. Jeollabuk-do: Jirisan Mt., elev. 1,300 m, Choi 6071 (JNU). Jeollanam-do, Sangwhangbong, elev. 1,900 m, Choi 3093 (JNU). 
Plectocolea truncata (Nees) Herzog 들망울이끼

Specimens examined: REPUBLIC OF KOREA. Chungcheongnam-do: Gyeryongsan Mt., elev. 290 m, Choi 4096 (JNU). Jejudo, Che Oruem, elev. 271 m, Choi 8059 (JNU), Cheonjiyeon waterfall, elev. 156 m, Choi 8878 (JNU).

Plectocolea virgata Mitt. 배루카망울이끼

Specimens examined: REPUBLIC OF KOREA. Jeju-do: Dongsu Brigde, elev. 653 m, Choi 111260 (JNU), Donnaeko Valley, elev. 200-350 m, Bakalin Kor-30-47-15 (VBGI); Dulle route, elev. 600-800 m, Bakalin Kor-29-21-15, Kor-29-5-15 (VBGI); Hyodon stream, elev. 484 m, Choi $7684 b$ (JNU).

Protosolenostoma fusiforme (Steph.) Vilnet \& Bakalin 방추형망울이끼

Specimens examined: REPUBLIC OF KOREA. Jeju-do: Bolre Oreum, elev. 1,230 m, Choi 111411 (JNU); Cryptomeria japonica reserved forest, elev. 329 m, Choi 8001 (JNU); Dongsu Brigde, elev. 653 m, Choi 111482 (JNU); Dulle route , elev. 600-800 m, Bakalin Kor-29-46-15 (VBGI); Hallasan Mt., elev. 1,916 m, Choi 7768 (JNU); Hyodon stream, elev. 484 m, Choi 111287 (JNU); Sumeunmulbyengdwi, elev. 992 m, Choi 8035 (JNU); Witse Oreum, elev. 1,668 m, Choi 120847 (JNU); Yeongsil valley, elev. 1,096 m, Choi 121070 (JNU). Jeollabuk-do: Deogyusan Mt., Choi 1039 (JNU). Jeollanam-do: Jirisan Mt., elev. 1,427 m, Choi $5042(\mathrm{JNU})$.

Solenostoma bilobum (Amakawa) Potemkin \& Nyushko 갈래망울이끼

Specimens examined: REPUBLIC OF KOREA. Gyeongsangnam-do: Jirisan Mt., elev. 1,720 m, Choi 3762 (JNU). Jeju-do: Seondol valley, elev. 311 m, Choi 110919 (JNU), Seogwipo-si, elev. 600-800 m, Bakalin Kor-29-27-15 (VBGI). Jeollabuk-do: Deogyusan Mt., elev. 700 m, Choi 3593 (JNU).

Solenostoma cyclops (S. Hatt.) R. M. Schust. 지리망울이끼

Specimens examined: REPUBLIC OF KOREA. Jeollabuk-do: Jirisan Mt., elev. 860 m, Choi 7279 (JNU).

Solenostoma faurianum (Beauverd) R. M. Schust. 하우리망울이끼

Specimens examined: REPUBLIC OF KOREA. Jeju-do: Quelpaert (=Jeju-do Island) 1906 U. Faurie (No. 106) G00115348 (Holotype; G).

Solenostoma jirisanense Bakalin \& S. S. Choi 칠선망울이끼

Specimens examined: REPUBLIC OF KOREA. Gyeongsangnam-do: Jirisan Mt., elev. 1,620 m, Choi 3747-3 (Holotype: JNU). Other specimens examined (paratypes): Gyeongsangnam-do: Jirisan Mt., elev. 1,300-1,400 m, Bakalin Kor-22-5-15; elev. 1,5001,600 m, Bakalin Kor-23-10-15, Kor-23-1-15; elev. 1,700-1,800 m, Bakalin Kor-25-5-15 (VBGI).

Solenostoma minutissimum (Amakawa) Bakalin 탐라망울이끼

Specimens examined: REPUBLIC OF KOREA. Jeju-do: Bolre Oreum, elev. 1,230 m, Choi 120745 (JNU); Hallasan Mt., elev. 1,861 m, Choi 120896 (JNU); Hyodon stream, elev. 541 m, Choi 111307 (JNU).

Solenostoma obscurum (A. Evans) R. M. Schust. 구슬망울이끼

Specimens examined: REPUBLIC OF KOREA. Gangwon-do: Seoraksan Mt., elev. 1,407 m, Choi 110353 (JNU).

Solenostoma purpuratum (Mitt.) Steph. var. koponenii Bakalin \& Li Wei 백무망울이끼

Specimens examined: REPUBLIC OF KOREA. Jeju-do: Goangryeongcheon stream, elev. 766 m, Choi 120375 (JNU).

Solenostoma pyriflorum Steph. 둥근망울이끼

Specimens examined: REPUBLIC OF KOREA. Gyeongsangbuk-do: Ulleungdo Isl., Seonginbong, 977 m, Choi 8724 (JNU). Gyeongsangnam-do: Jirisan Mt., elev. 1,915 m, Choi 8217 (JNU). Jeju-do: Dulle route, elev. 600-800 m, Bakalin Kor-29-66-15 (VBGI). 
Solenostoma rotundatum Amakawa 산망울이끼

Specimens examined: REPUBLIC OF KOREA. Chungcheongnam-do: Gyeryongsan Mt., elev. 290 m, Choi 4091 (JNU). Gangwon-do: Hambaeksan Mt., Choi 4147 (JNU). Gyeongsangbuk-do: Sobaeksan Mt., elev. 569 m, Choi 4304 (JNU). Gyeongsangnam-do: Deogyusan Mt., Choi 468 (JNU); Gayasan Mt., elev. 585 m, Choi 4355 (JNU); Jirisan Mt., elev. 720 m, Choi 3618 (JNU). Jeju-do: Donnaeko stream, elev. 172 m, Choi 111381 (JNU). Jeollabuk-do: Deogyusan Mt., Choi 362 (JNU); Deogyusan Mt., Choi 865 (JNU); Jirisan Mt., elev. 685 m, Choi 7343 (JNU). Jeollanam-do: Cheongsan-do Isl., elev. 350 m, Choi (JNU); Oenarodo Isl., Bongraesan Mt., elev. 120 m, Choi 110580 (JNU); Seongdudo Isl., elev. 7 m, Choi 110605 (JNU); Duryunsan Mt., elev. 262 m, Choi 110450 (JNU); Naejangsan Mt., Choi $3594 b$ (JNU), Palyeoungsan Mt., elev. 298 m, Choi 4012 (JNU).

\section{Solenostoma sunii Bakalin \& Vilnet 선망울이끼}

Specimens examined: REPUBLIC OF KOREA. Gyeongsangnam-do: Jirisan Mt., elev. 848 m, Choi 3653 (JNU); elev. 144 m, Choi 3710 (JNU); elev. 1,720 m, Choi 3759 (JNU); Gayasan Mt., elev. 1,350 m, Choi 7415 (JNU); elev. 1,500-1,600 m, Bakalin Kor-23-11-15 (VBGI); elev. 1,700-1,800 m, Bakalin Kor-25-14-15 (VBGI). Jeju-do: Bolre Oreum, elev. 1,230 m, Choi 111425 (JNU). Jeollabuk-do: Deogyusan Mt., Choi 878 (JNU); Jirisan Mt., elev. 1,300 m, Choi 6055 (JNU). 